\title{
Development of Azo-Based Turn-On Chemical Array System for Hydrazine Detection with Fluorescence Pattern Analysis
}

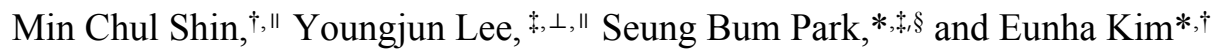 \\ $†$ Department of Molecular Science and Technology, Ajou University, Suwon 16499, Korea \\ ¥CRI Center for Chemical Proteomics, Department of Chemistry, Seoul National University, Seoul 08826, Korea \\ ${ }^{\perp}$ Department of Chemistry and Biochemistry, University of California, San Diego, La Jolla, CA 92093, USA \\ ${ }^{\S}$ Department of Biophysics and Chemical Biology, Seoul National University, Seoul 08826, Korea \\ ("These authors equally contributed to this work) \\ *Correspondence to : sbpark@snu.ac.kr, ehkim01@ajou.ac.kr \\ i
}


Synthesis of methyl 3-(piperazin-1-yl)propanoate

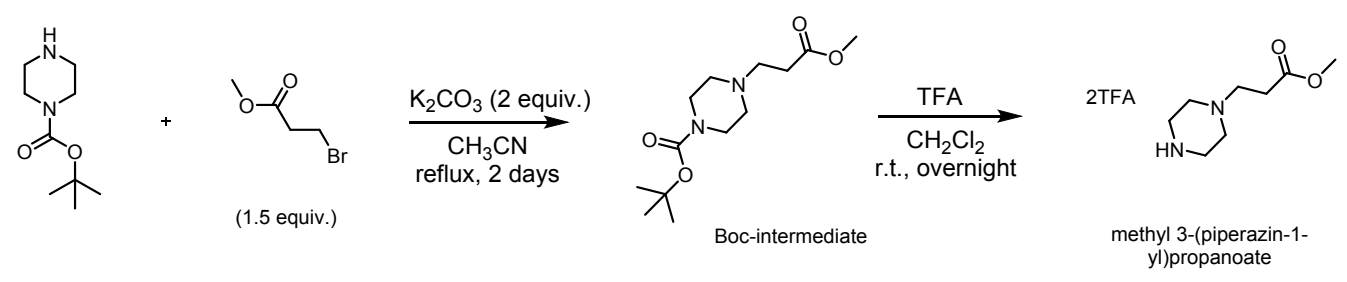

Boc-intermediate: tert-Butyl piperazine-1-carboxylate $(800 \mathrm{mg}, 4.30 \mathrm{mmol})$, methyl 3-bromopropionate $(1.08 \mathrm{~g}$, $6.44 \mathrm{mmol})$, and potassium carbonate $(1.19 \mathrm{~g}, 8.59 \mathrm{mmol})$ were dissolved in acetonitrile $(6.5 \mathrm{~mL})$. The mixture was stirred at reflux condition for 2 days. The resulting residue was washed with saturated $\mathrm{NaHCO}_{3}$ aqueous solution, extracted with $\mathrm{CH}_{2} \mathrm{Cl}_{2}$, dried over anhydrous $\mathrm{Na}_{2} \mathrm{SO}_{4}$, and concentrated. The crude product was purified by flash column chromatography (silica gel, $\left.\mathrm{CH}_{2} \mathrm{Cl}_{2}: \mathrm{CH}_{3} \mathrm{OH}=40: 1\right)$ to afford Boc-intermediate $(1.12 \mathrm{~g}, 4.11 \mathrm{mmol}, 95.7 \%$ yield) as a transparent oil; ${ }^{1} \mathrm{H}$ NMR $\left(400 \mathrm{MHz}, \mathrm{CDCl}_{3}\right) \delta 3.69(\mathrm{~s}, 3 \mathrm{H}), 3.41(\mathrm{t}, J=5.1 \mathrm{~Hz}, 4 \mathrm{H}), 2.70(\mathrm{t}, J=7.2 \mathrm{~Hz}, 2 \mathrm{H})$, $2.51(\mathrm{t}, J=7.4 \mathrm{~Hz}, 2 \mathrm{H}), 2.40$ (t, $J=5.1 \mathrm{~Hz}, 4 \mathrm{H}), 1.46(\mathrm{~s}, 9 \mathrm{H}) ;{ }^{13} \mathrm{C} \mathrm{NMR}\left(100 \mathrm{MHz}, \mathrm{CDCl}_{3}\right) \delta 172.8,154.7,79.6,53.6$, 52.7, 51.7, 51.7, 32.1, 28.4; LRMS (ESI) $m / z$ calcd for $\mathrm{C}_{13} \mathrm{H}_{25} \mathrm{~N}_{2} \mathrm{O}_{4}[\mathrm{M}+\mathrm{H}]^{+}: 273.18$, found: 273.15 .

methyl 3-(piperazin-1-yl)propanoate: Boc-intermediate $(583.6 \mathrm{mg}, 2.14 \mathrm{mmol}$ ) and trifluoroacetic acid (TFA, 1.49 $\mathrm{g}, 13.1 \mathrm{mmol}, 1.00 \mathrm{~mL})$ were dissolved in $\mathrm{CH}_{2} \mathrm{Cl}_{2}(10 \mathrm{~mL})$. The mixture was stirred at room temperature for overnight. Solvent was removed under the reduced pressure. Proceed to the next step without further purifications; ${ }^{1} \mathrm{H}$ NMR (400 $\left.\mathrm{MHz}, \mathrm{CD}_{3} \mathrm{OD}\right) \delta 3.71(\mathrm{~s}, 3 \mathrm{H}), 3.45$ (t, $\left.J=5.5 \mathrm{~Hz}, 4 \mathrm{H}\right), 3.19-3.37$ (m, 6H), 2.79 (t, $\left.J=6.8 \mathrm{~Hz}, 2 \mathrm{H}\right) ;{ }^{13} \mathrm{C}$ NMR $(100 \mathrm{MHz}$, $\left.\mathrm{CD}_{3} \mathrm{OD}\right) \delta 172.8,53.9,52.6,50.3,42.9,30.6$; LRMS (ESI) $\mathrm{m} / z$ calcd for $\mathrm{C}_{8} \mathrm{H}_{17} \mathrm{~N}_{2} \mathrm{O}_{2}[\mathrm{M}+\mathrm{H}]^{+}: 173.13$, found: 173.10 . 
Table S1. Reaction Condition Optimization for Intramolecular 1,3-Dipolar Cycloaddition.

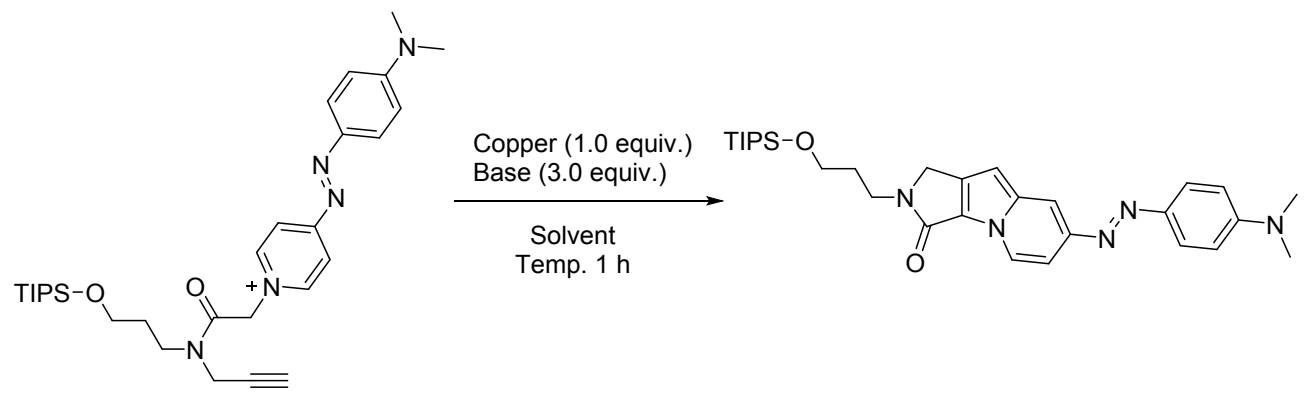

\begin{tabular}{|c|c|c|c|c|c|}
\hline & $\operatorname{Temp}\left({ }^{\circ} \mathrm{C}\right)$ & Base & Solvent & Copper & Product Yield $^{\mathrm{a}}$ \\
\hline 1 & 25 & $\mathrm{~K}_{2} \mathrm{CO}_{3}$ & $\mathrm{CH}_{3} \mathrm{CN}$ & - & - \\
\hline 2 & 25 & $\mathrm{~N}\left(\mathrm{CH}_{2} \mathrm{CH}_{3}\right)_{3}$ & $\mathrm{CH}_{3} \mathrm{CN}$ & - & - \\
\hline 3 & 25 & $\mathrm{~N}\left(\mathrm{CH}_{2} \mathrm{CH}_{3}\right)_{3}$ & $\mathrm{CH}_{3} \mathrm{CN}$ & $\mathrm{CuI}$ & - \\
\hline 4 & 25 & DBU & $\mathrm{CH}_{3} \mathrm{CN}$ & - & trace \\
\hline 5 & 0 & $\mathrm{DBU}$ & $\mathrm{CH}_{3} \mathrm{CN}$ & $\mathrm{CuI}$ & trace \\
\hline 6 & 25 & $\overline{\mathrm{DBU}}$ & $\mathrm{CH}_{3} \mathrm{CN}$ & $\mathrm{CuI}$ & 6 \\
\hline 7 & 50 & DBU & $\mathrm{CH}_{3} \mathrm{CN}$ & $\mathrm{CuI}$ & 6 \\
\hline 8 & 80 & $\mathrm{DBU}$ & $\mathrm{CH}_{3} \mathrm{CN}$ & $\mathrm{CuI}$ & 20 \\
\hline 9 & 80 & DBU & 1,2-dichloroethane & $\mathrm{CuI}$ & 21 \\
\hline 10 & 80 & $\mathrm{DBU}$ & DMF & $\mathrm{CuI}$ & 23 \\
\hline 11 & 80 & $\mathrm{DBU}$ & Toluene & $\mathrm{CuI}$ & 21 \\
\hline 12 & 110 & $\overline{\mathrm{DBU}}$ & Toluene & $\mathrm{CuI}$ & 22 \\
\hline 13 & 120 & DBU & DMF & $\mathrm{CuI}$ & 30 \\
\hline 14 & 120 & DBU & dry DMF & $\mathrm{CuI}$ & 25 \\
\hline 15 & 120 & DBU & DMF & $\mathrm{CuCN}$ & 25 \\
\hline 16 & 120 & DBU & DMF & $\mathrm{CuCl}$ & 31 \\
\hline 17 & 120 & $\mathrm{DBU}$ & DMF & $\mathrm{CuBr}$ & 22 \\
\hline
\end{tabular}

${ }^{a}$ NMR Yield estimation 


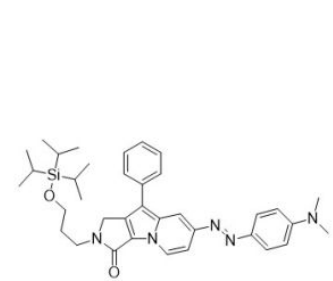

S3

cLogP value

10.08

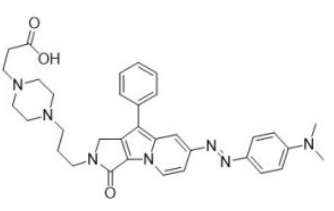

SF-Azo 01

cLogP value

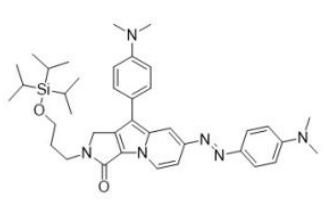

S4

10.24

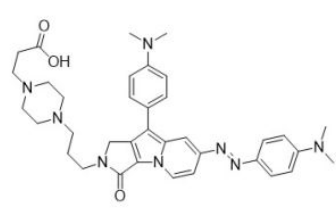

SF-Azo 02

3.10

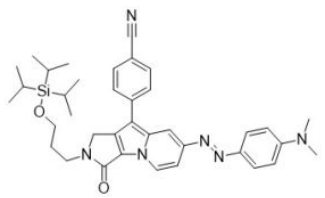

S5

9.51

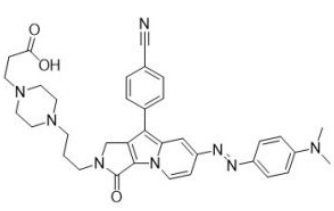

SF-Azo 03

2.37

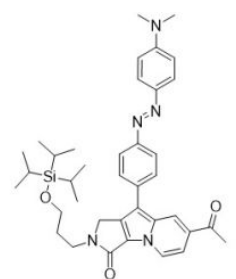

S7

9.59

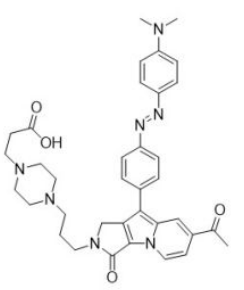

SF-Azo 04

2.44

Figure S1. Chemical structures and cLogP values for S3, S4, S5, S7, and SF-Azo 01-04. 

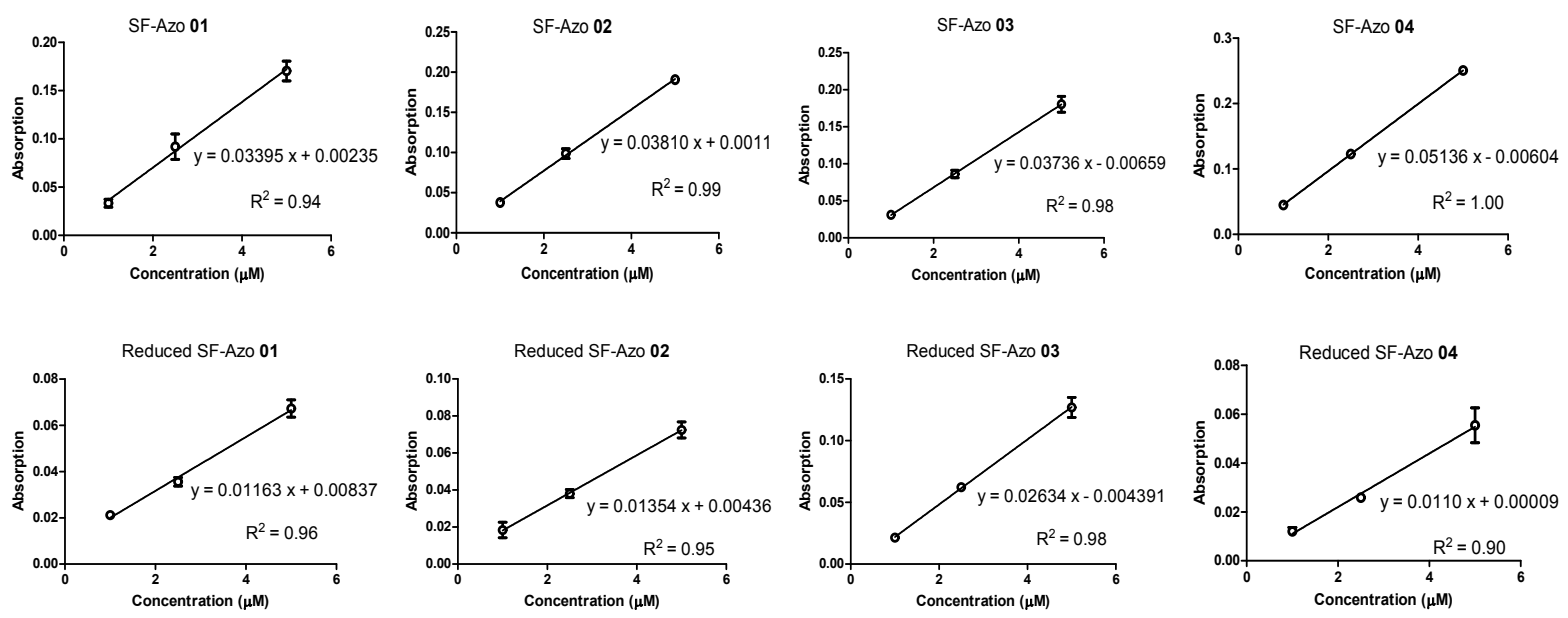

Figure S2. The linear plots of SF-Azo concentration versus absorption intensity. Each slope represents a 1:106 scale of molar absorptivity $(\varepsilon)$ for corresponding SF-Azo or its reduced species. 


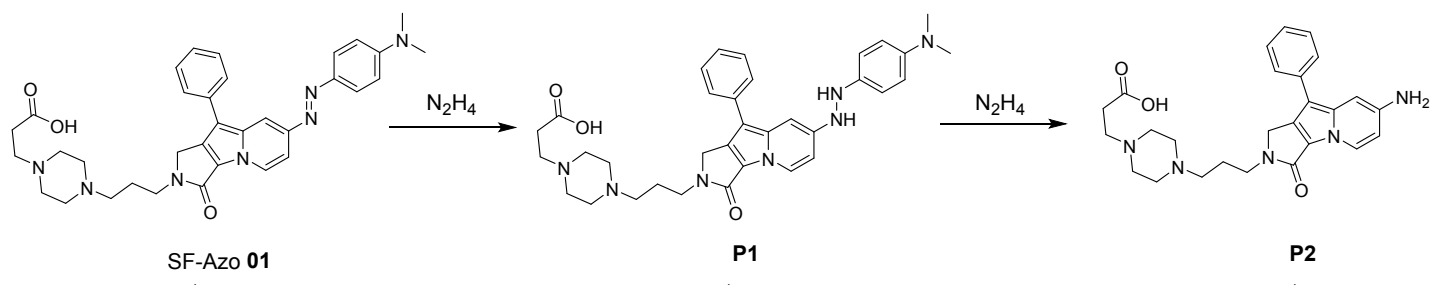

$[\mathrm{M}+\mathrm{H}]^{+}=594.32$

$[\mathrm{M}+\mathrm{H}]^{+}=596.34$

$[\mathrm{M}+\mathrm{H}]^{+}=462.25$

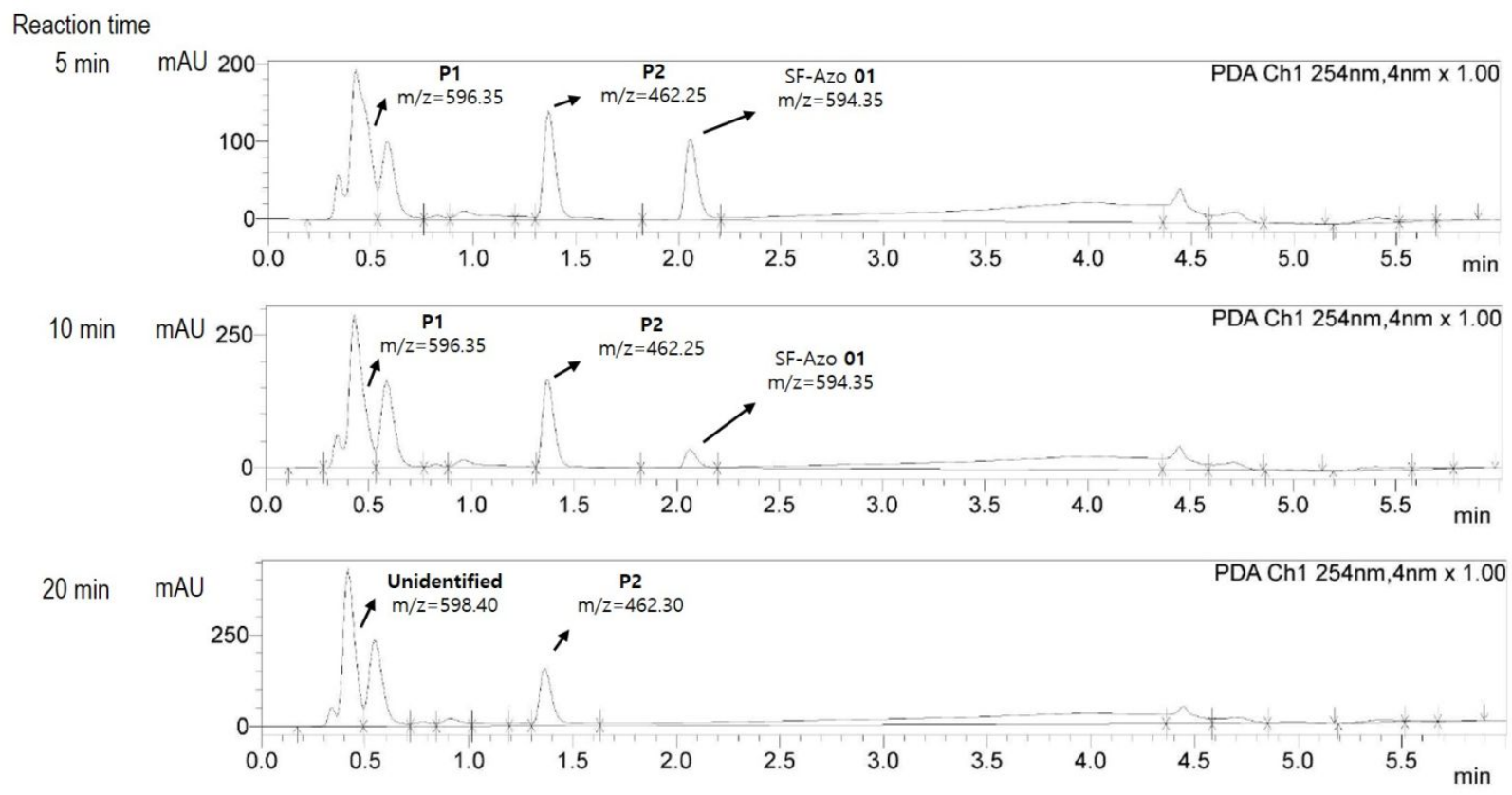

Figure S3. Proposed reduction structures of SF-Azo 01 and time relevant LC/MS data of hydrazine treated SF-Azo 01. SF-Azo $01(100 \mu \mathrm{M})$ was incubated with hydrazine monohydrate $(200 \mathrm{mM})$ in methanol and water mixture $(0.5$ $\mathrm{mL}, \mathrm{v}: \mathrm{v}=1: 1)$ at $50^{\circ} \mathrm{C}$. Data were measured at 5,10 , and $20 \mathrm{~min}$. 

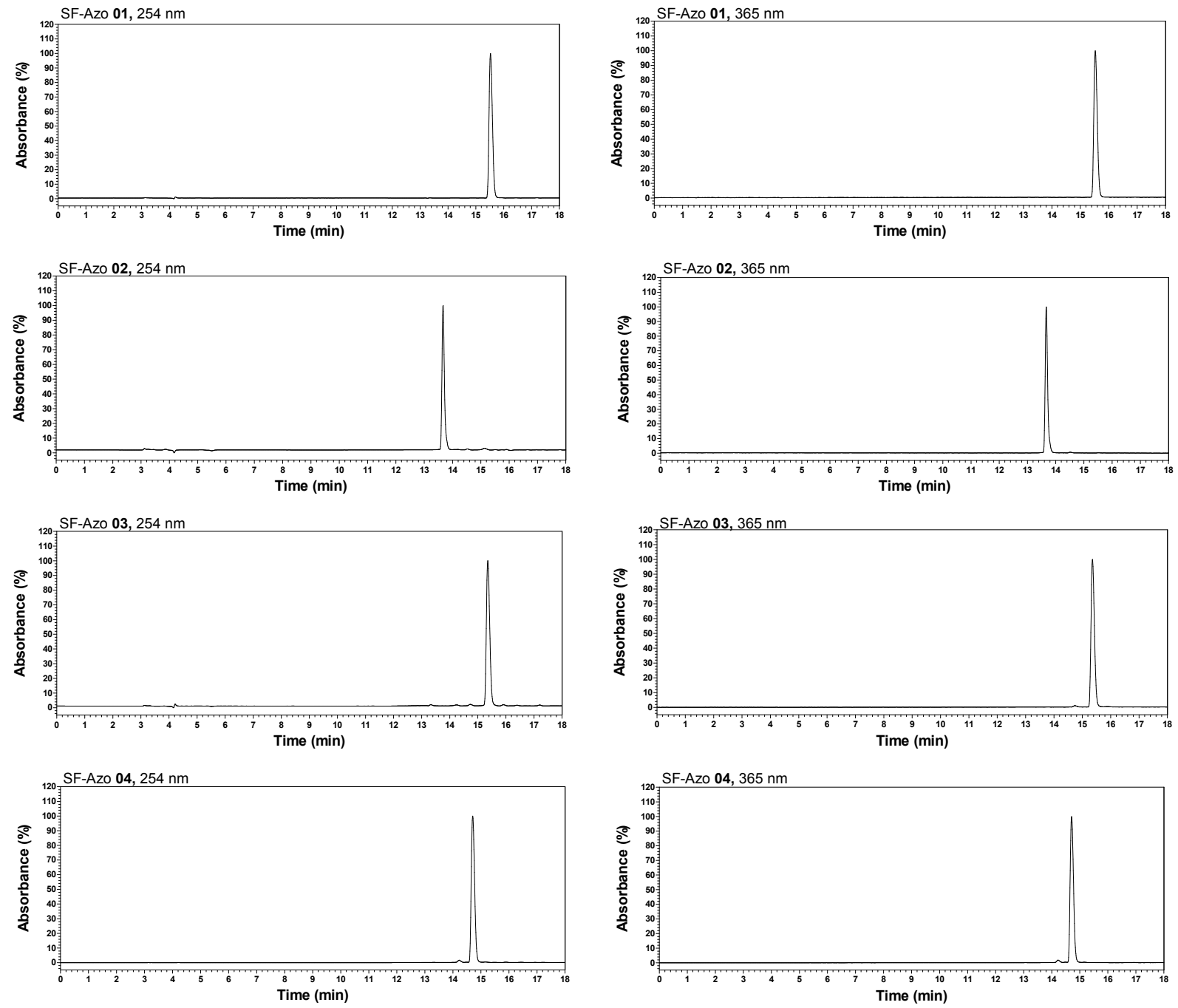

Figure S4. Purity of SF-Azo 01-04 was confirmed by HPLC analysis. 
Figure S5. ${ }^{1} \mathrm{H}$ and ${ }^{13} \mathrm{C}$ NMR spectra for compound Boc-intermediate
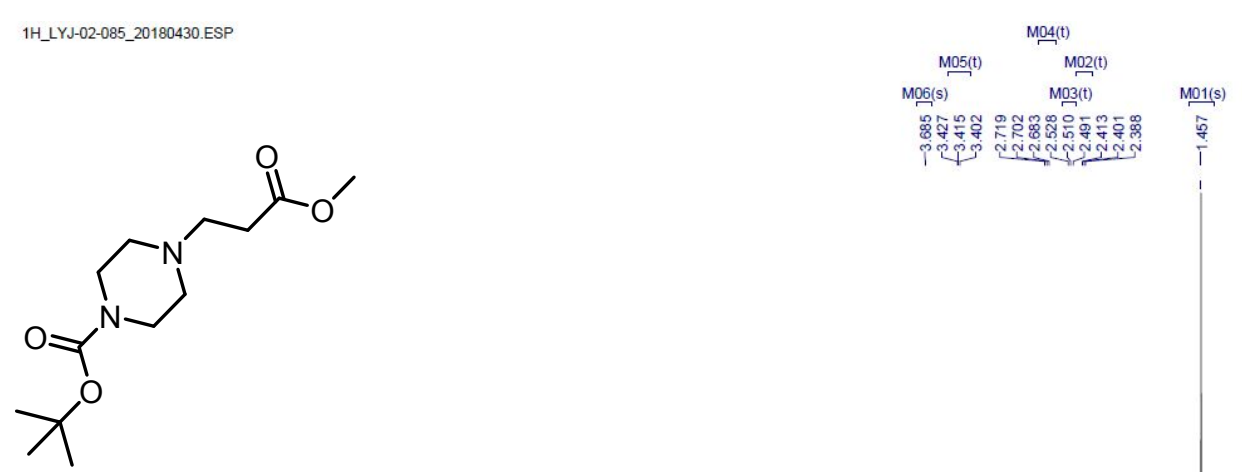

Boc-intermediate

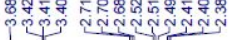

के

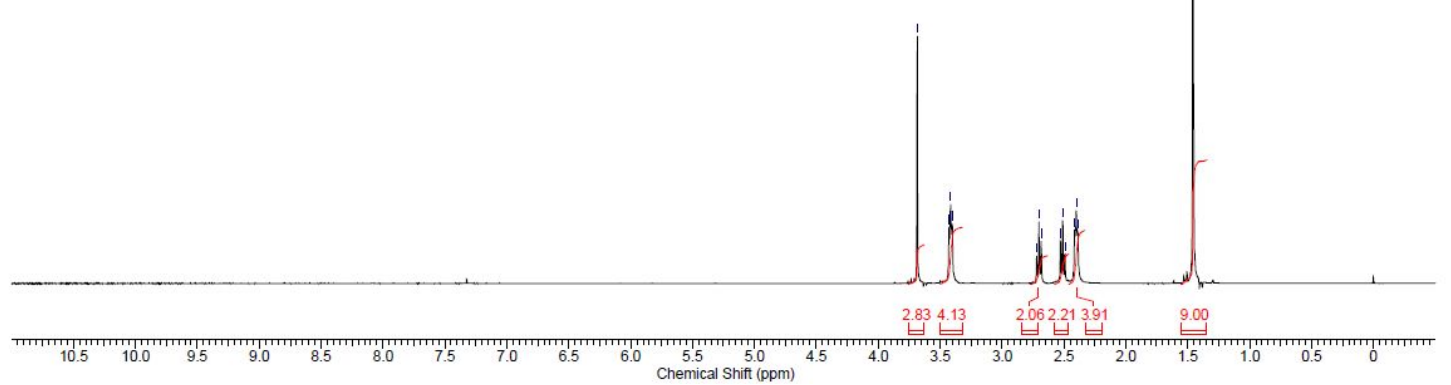
13C_LYJ-02-085_CARBON_20180430.ESP $\begin{array}{ll}\frac{1}{i} & \overline{0} \\ \stackrel{5}{0} & \frac{1}{0}\end{array}$
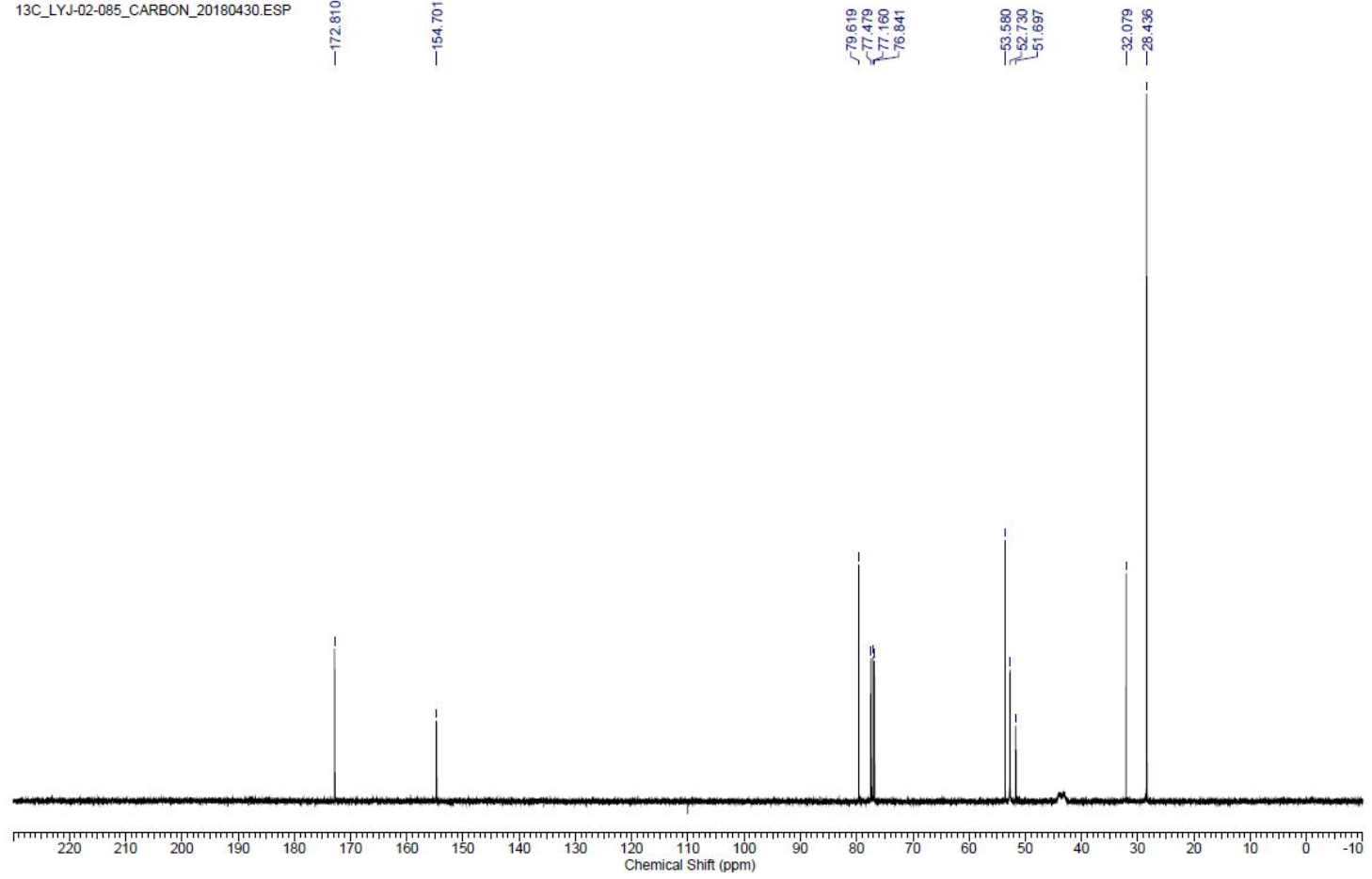
Figure S6. ${ }^{1} \mathrm{H}$ and ${ }^{13} \mathrm{C}$ NMR spectra for compound methyl 3-(piperazin-1-yl)propanoate

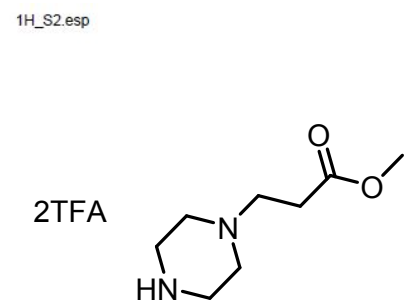

methyl 3-(piperazin-1-yl)propanoate

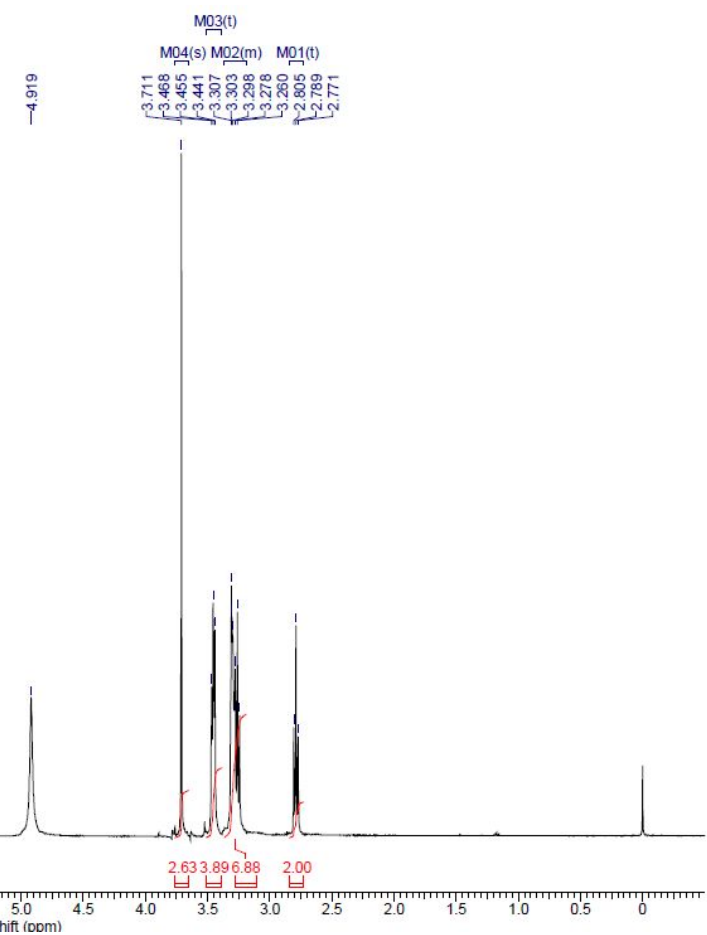

13C_LYJ-02-086_MEOD-D4_CARBON_20180508娒SP

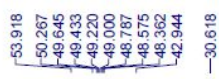

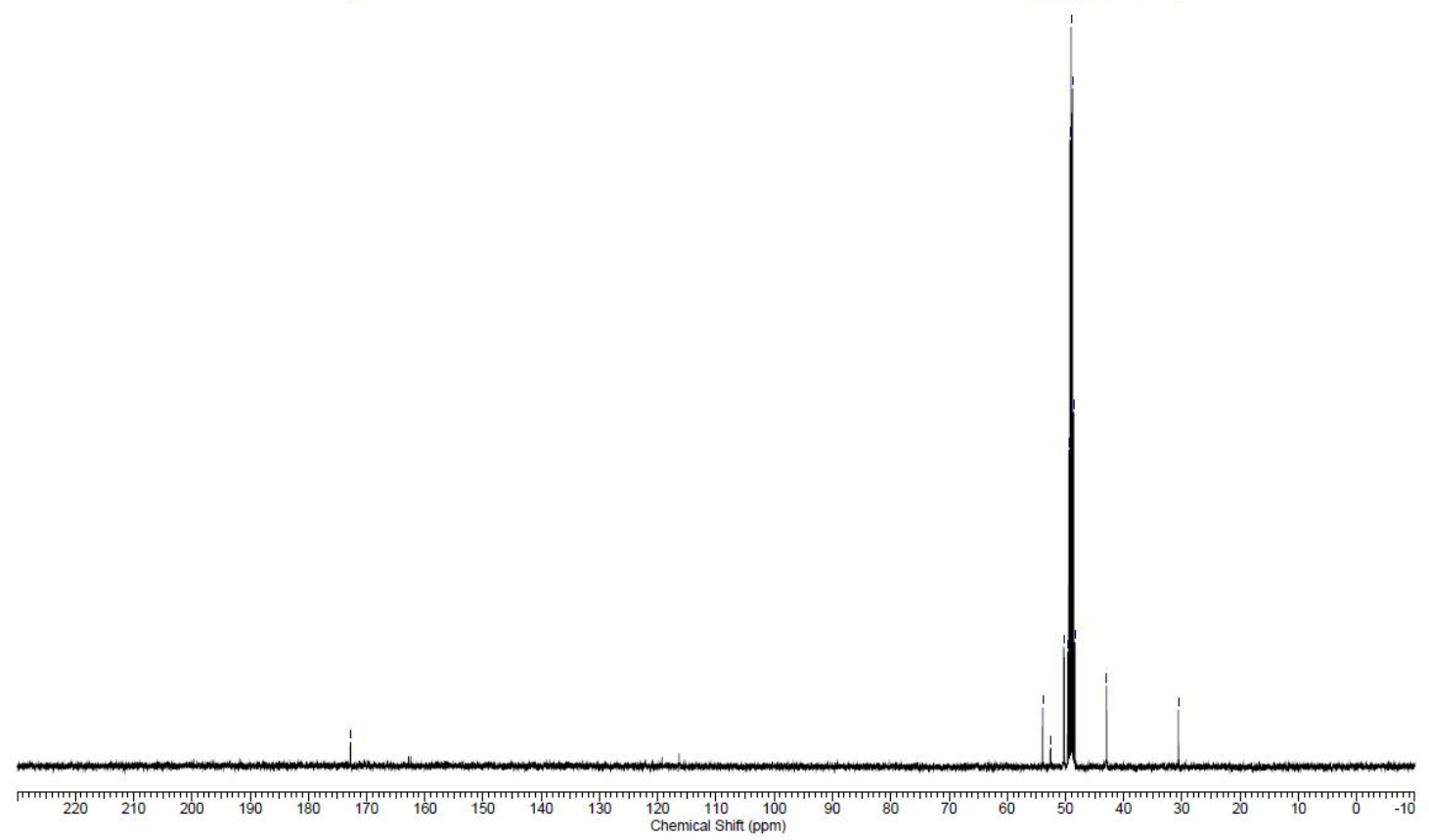


Figure S7. ${ }^{1} \mathrm{H}$ and ${ }^{13} \mathrm{C}$ NMR spectra for compound $\mathrm{S} 1$
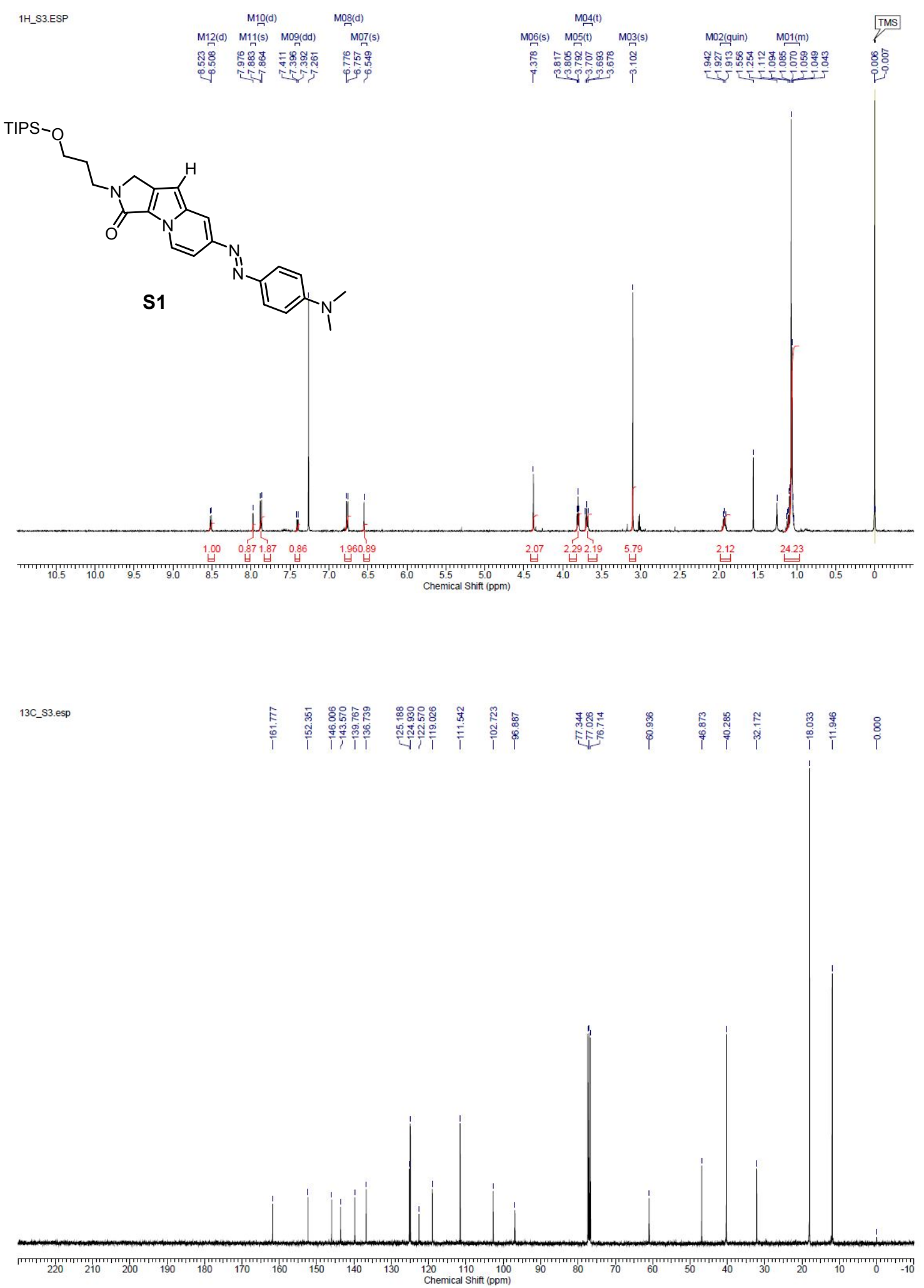
Figure S8. ${ }^{1} \mathrm{H}$ and ${ }^{13} \mathrm{C}$ NMR spectra for compound S2

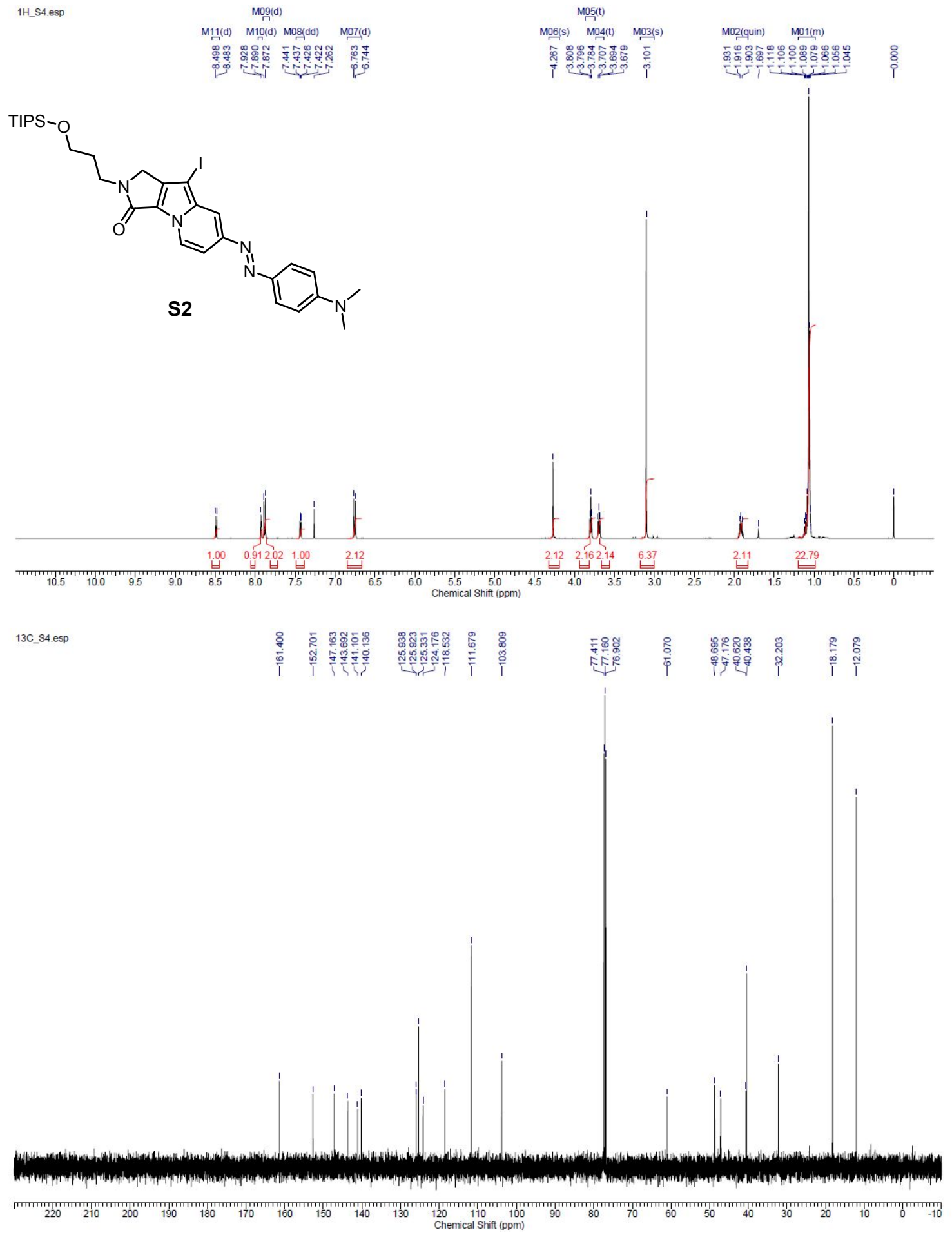


Figure S9. ${ }^{1} \mathrm{H}$ and ${ }^{13} \mathrm{C}$ NMR spectra for compound S3

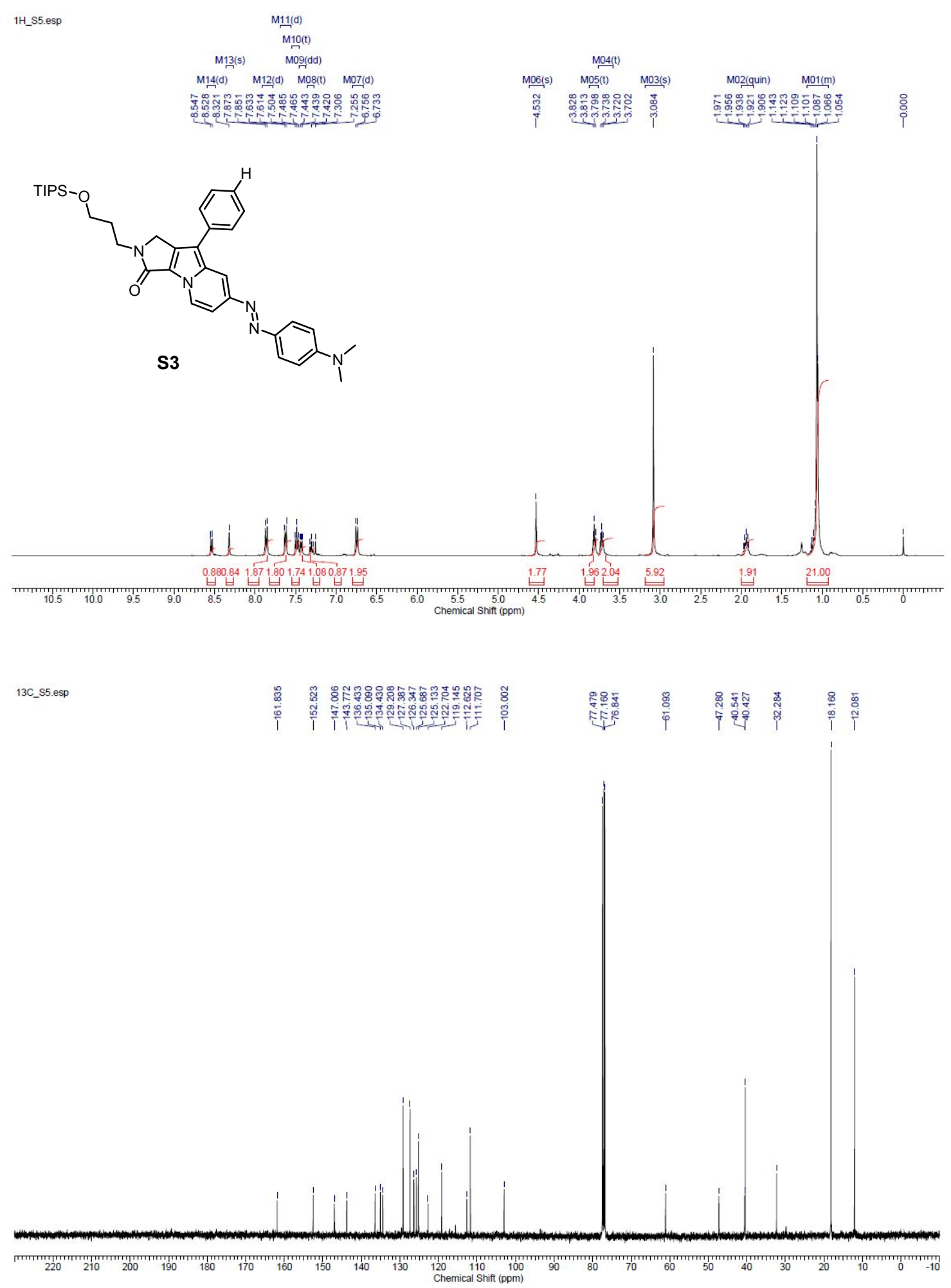


Figure S10. ${ }^{1} \mathrm{H}$ and ${ }^{13} \mathrm{C}$ NMR spectra for compound $\mathrm{S} 4$
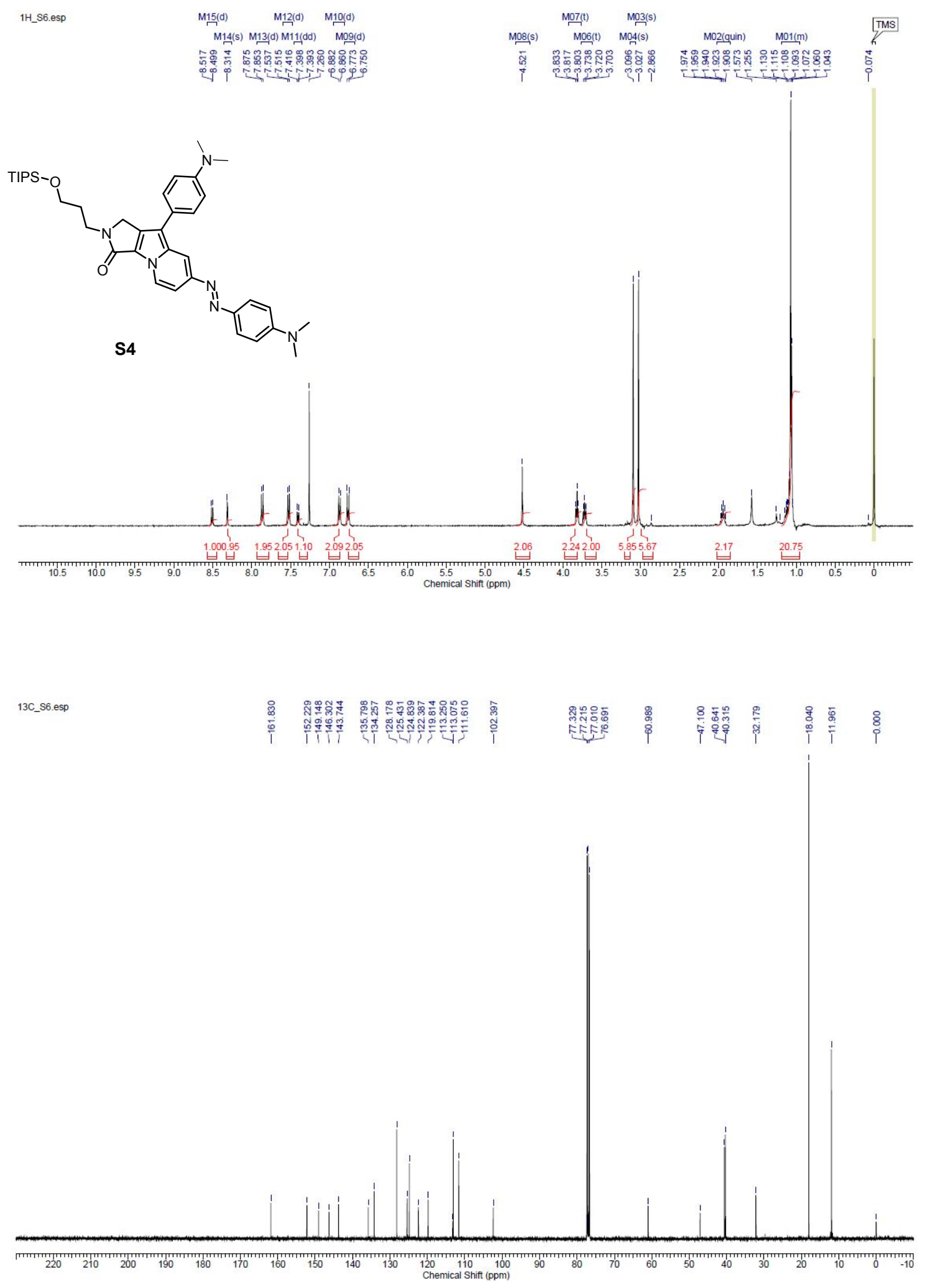
Figure S11. ${ }^{1} \mathrm{H}$ and ${ }^{13} \mathrm{C}$ NMR spectra for compound S5
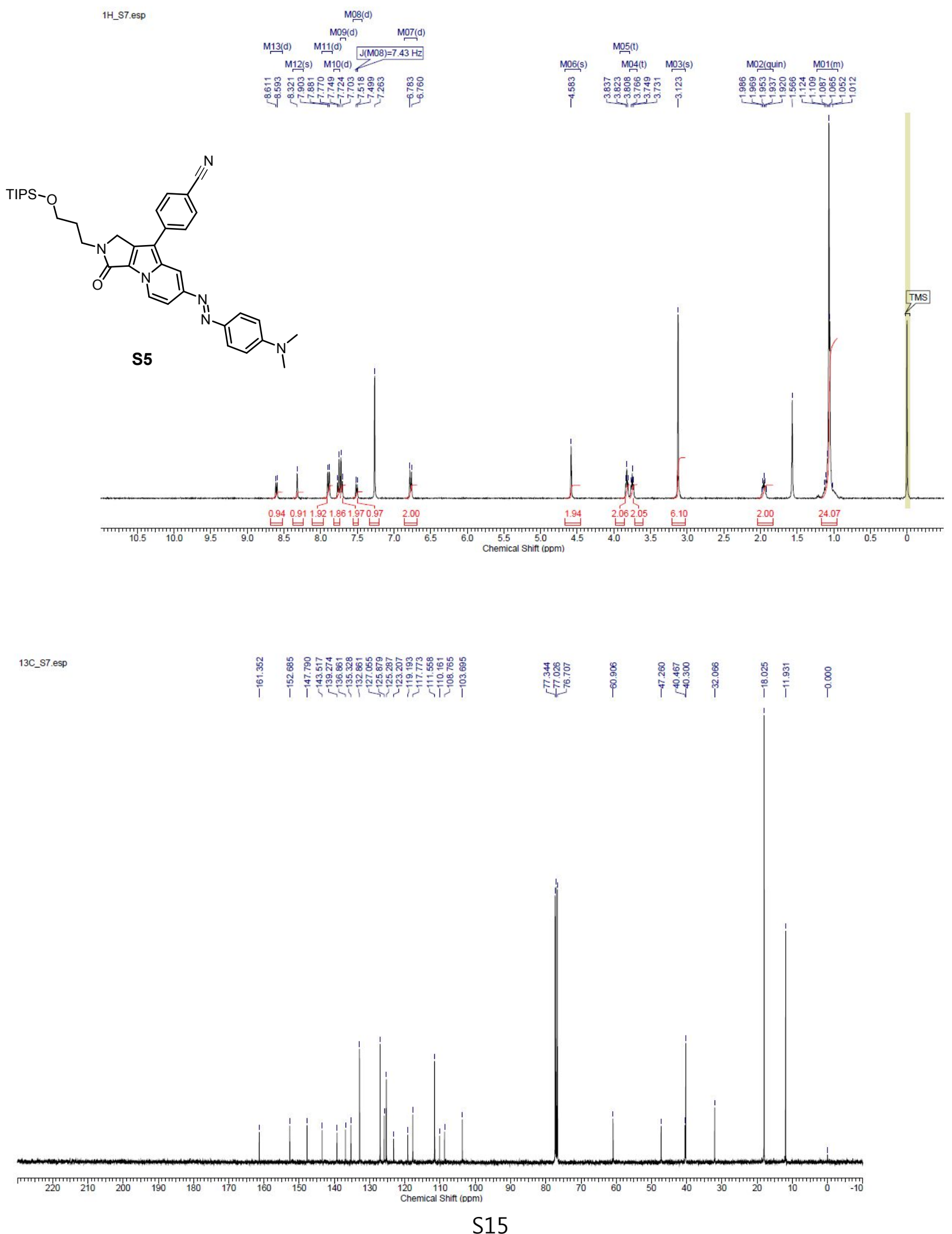
Figure S12. ${ }^{1} \mathrm{H}$ and ${ }^{13} \mathrm{C}$ NMR spectra for compound S6

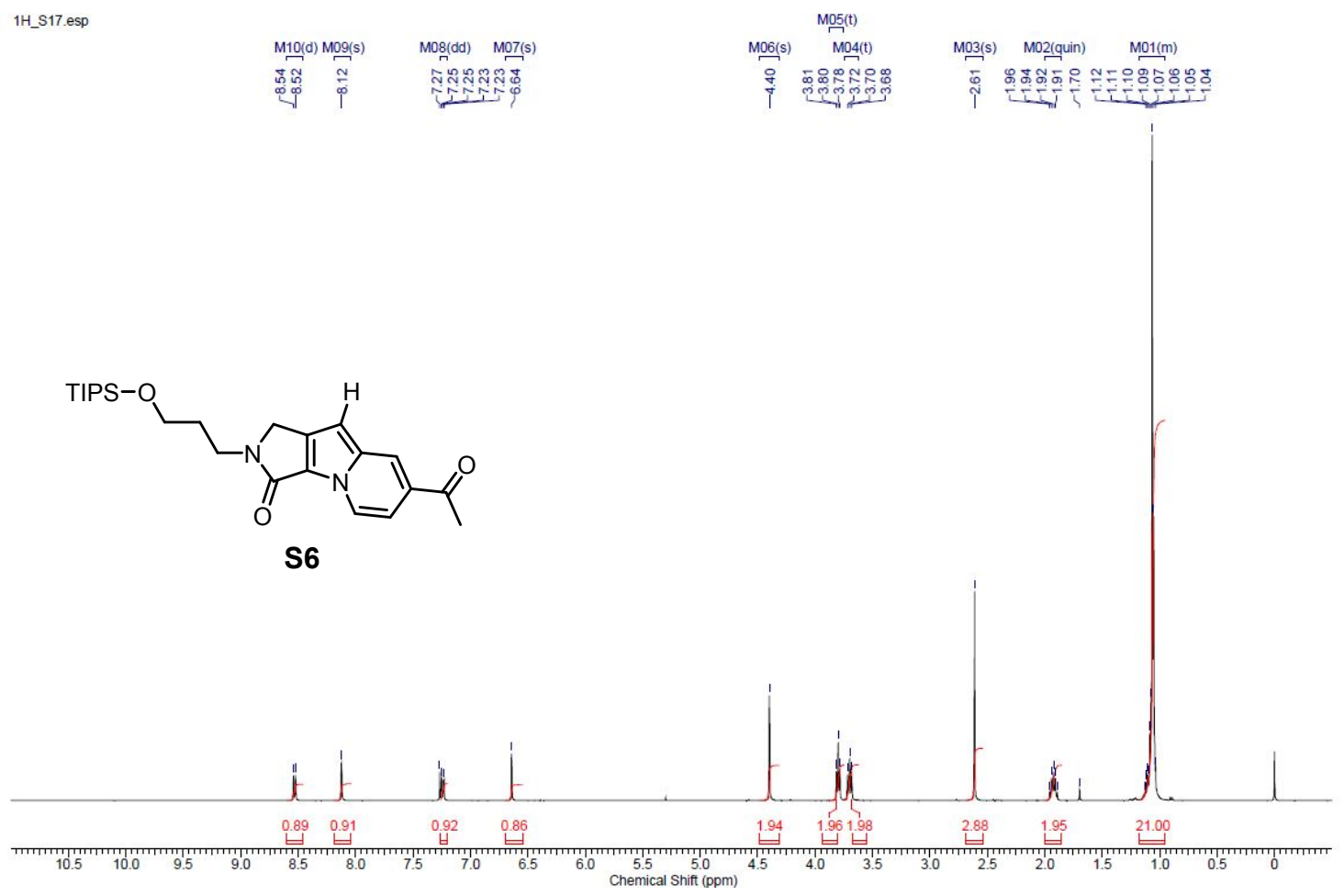

13C_S17.ESP

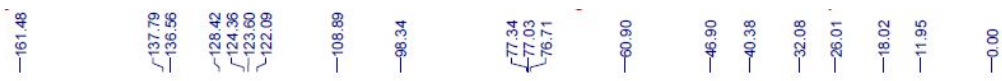

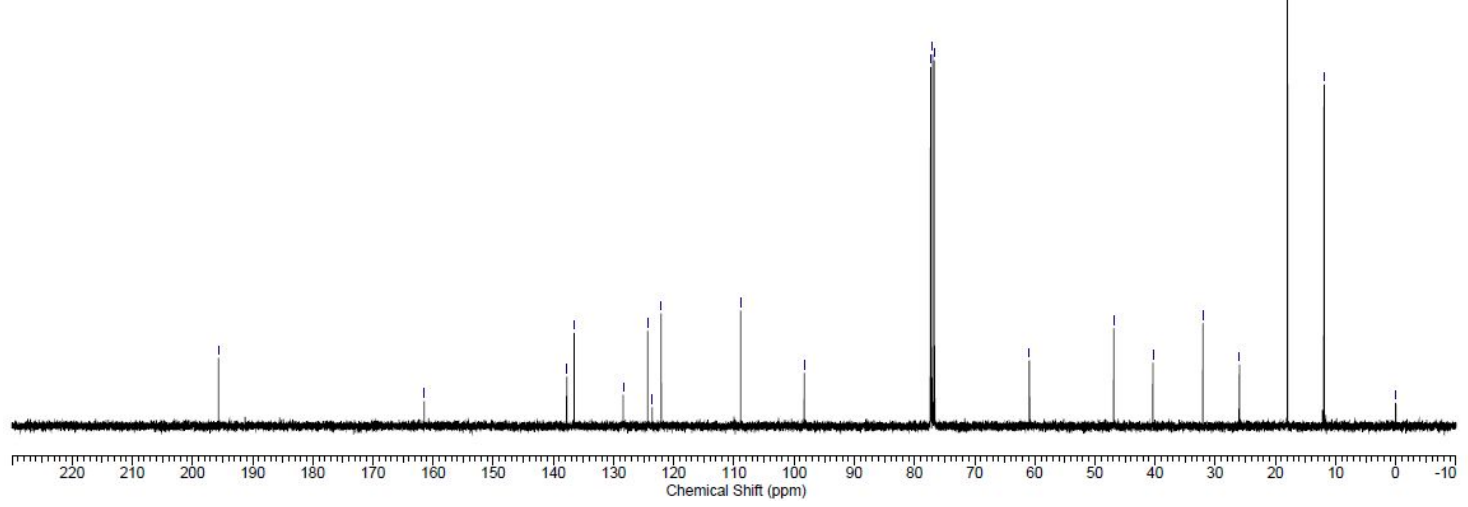


Figure S13. ${ }^{1} \mathrm{H}$ and ${ }^{13} \mathrm{C}$ NMR spectra for compound $\mathrm{S} 7$

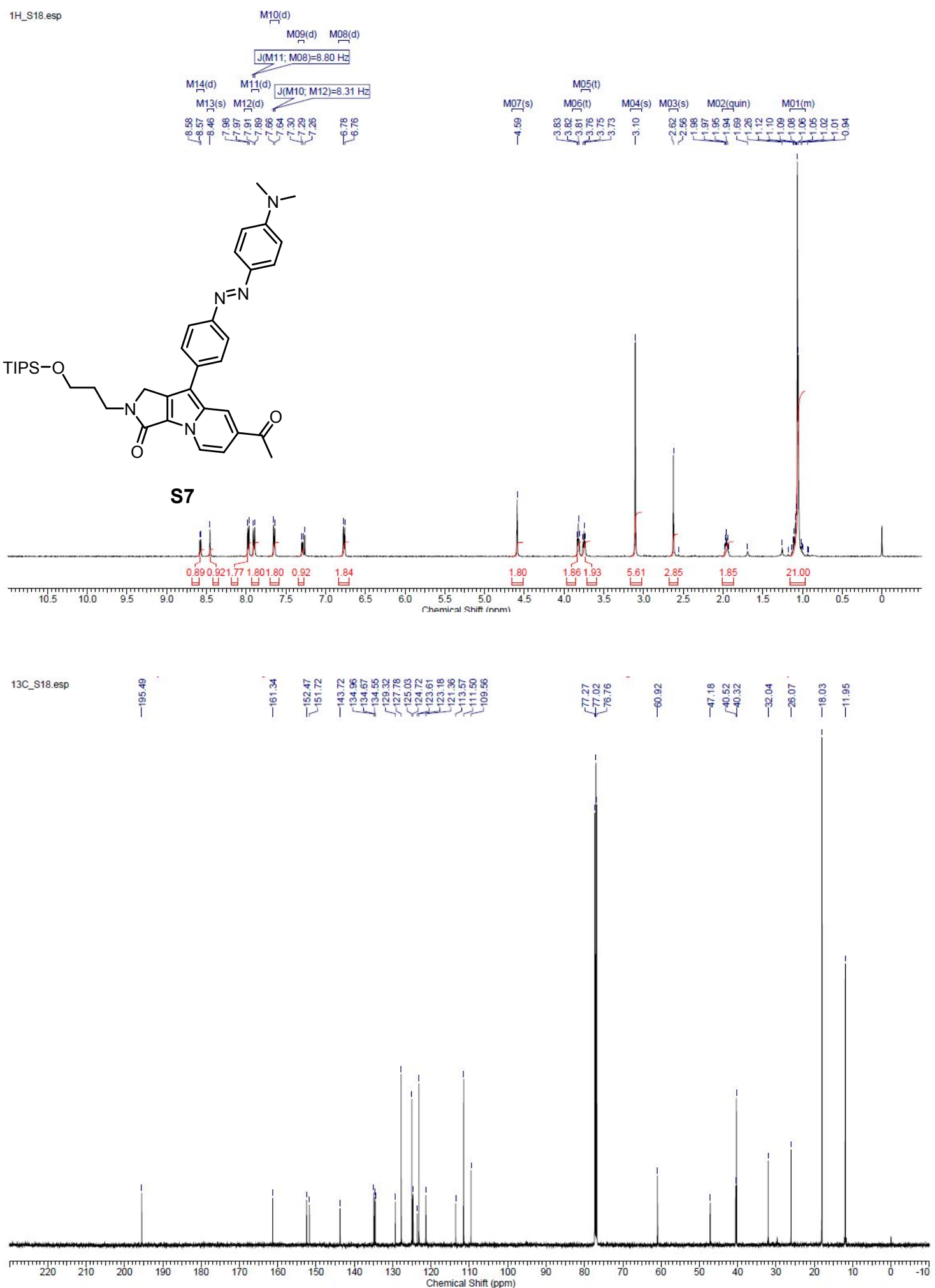


Figure S14. ${ }^{1} \mathrm{H}$ and ${ }^{13} \mathrm{C}$ NMR spectra for compound $\mathrm{S} 8$
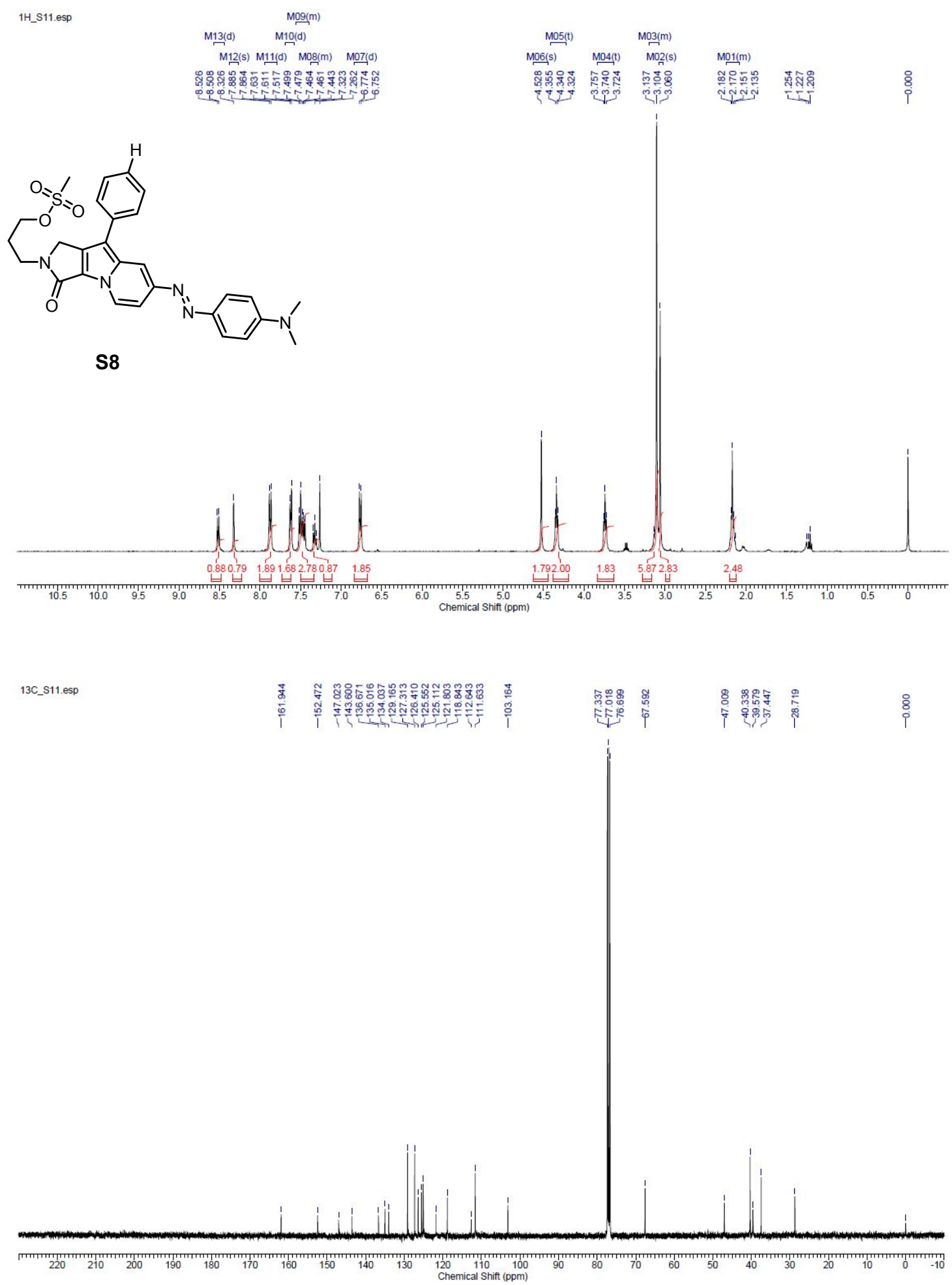
Figure S15. ${ }^{1} \mathrm{H}$ and ${ }^{13} \mathrm{C}$ NMR spectra for compound S9

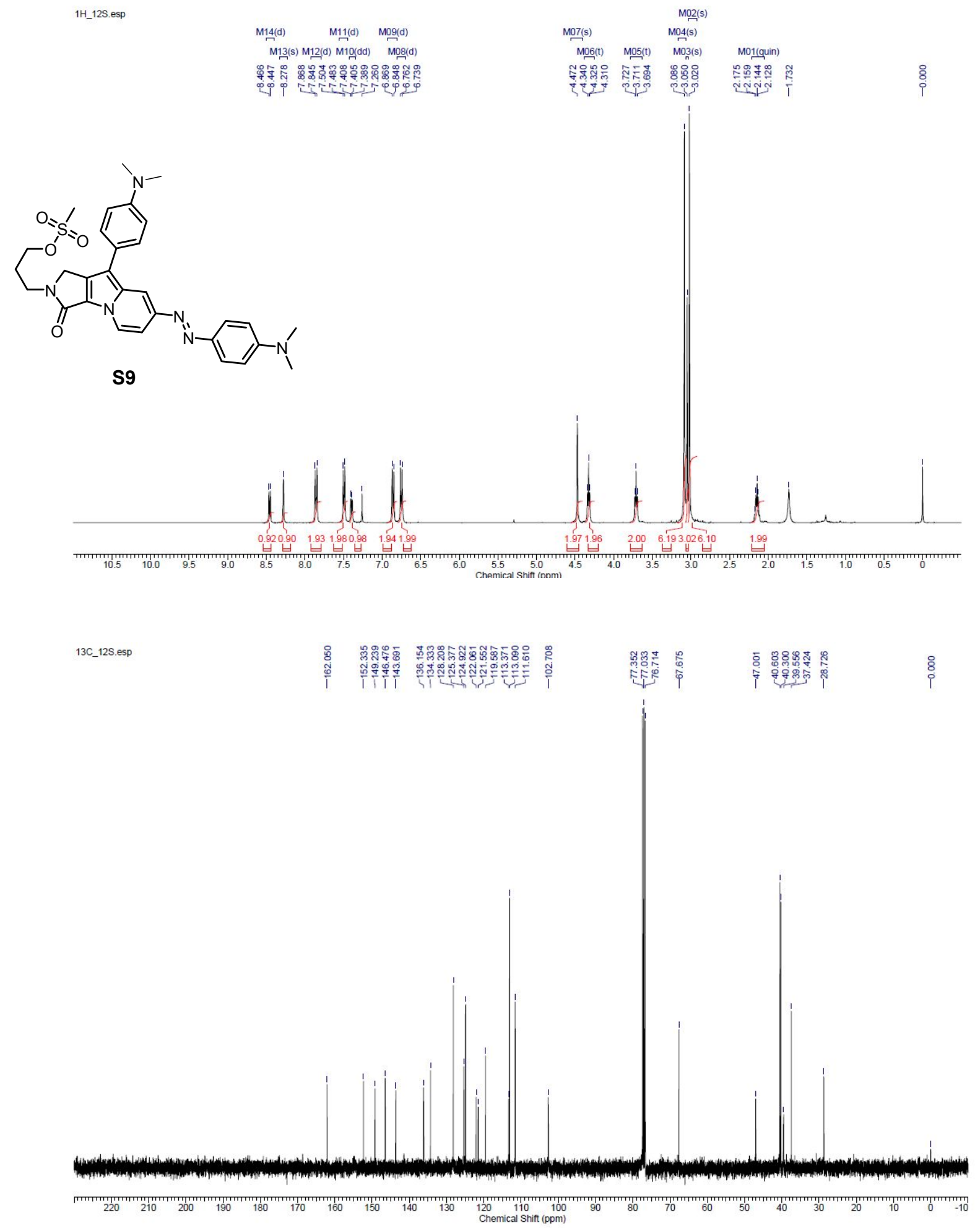


Figure S16. ${ }^{1} \mathrm{H}$ and ${ }^{13} \mathrm{C}$ NMR spectra for compound $\mathrm{S} 10$
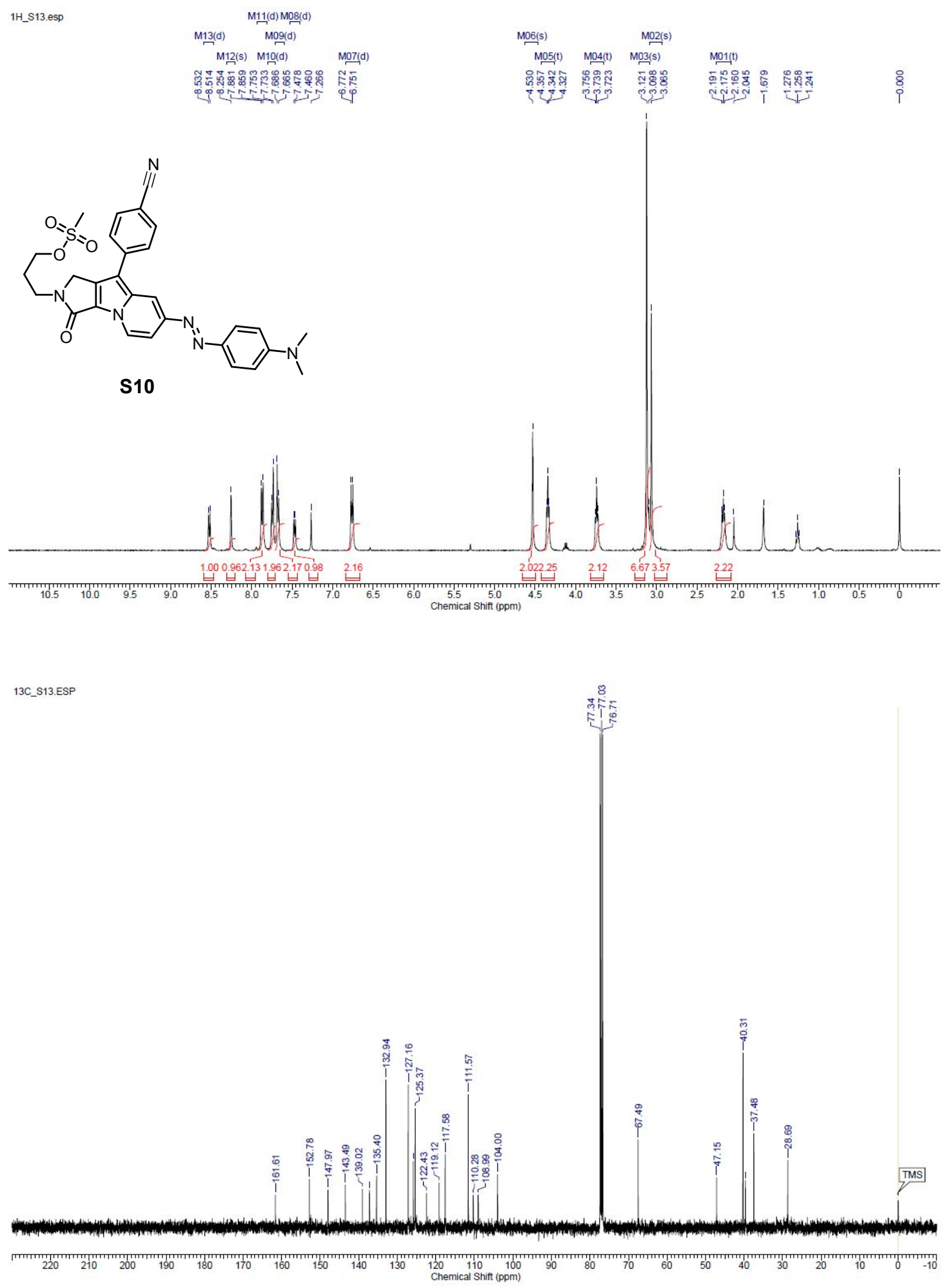
Figure S17. ${ }^{1} \mathrm{H}$ and ${ }^{13} \mathrm{C}$ NMR spectra for compound $\mathrm{S} 11$

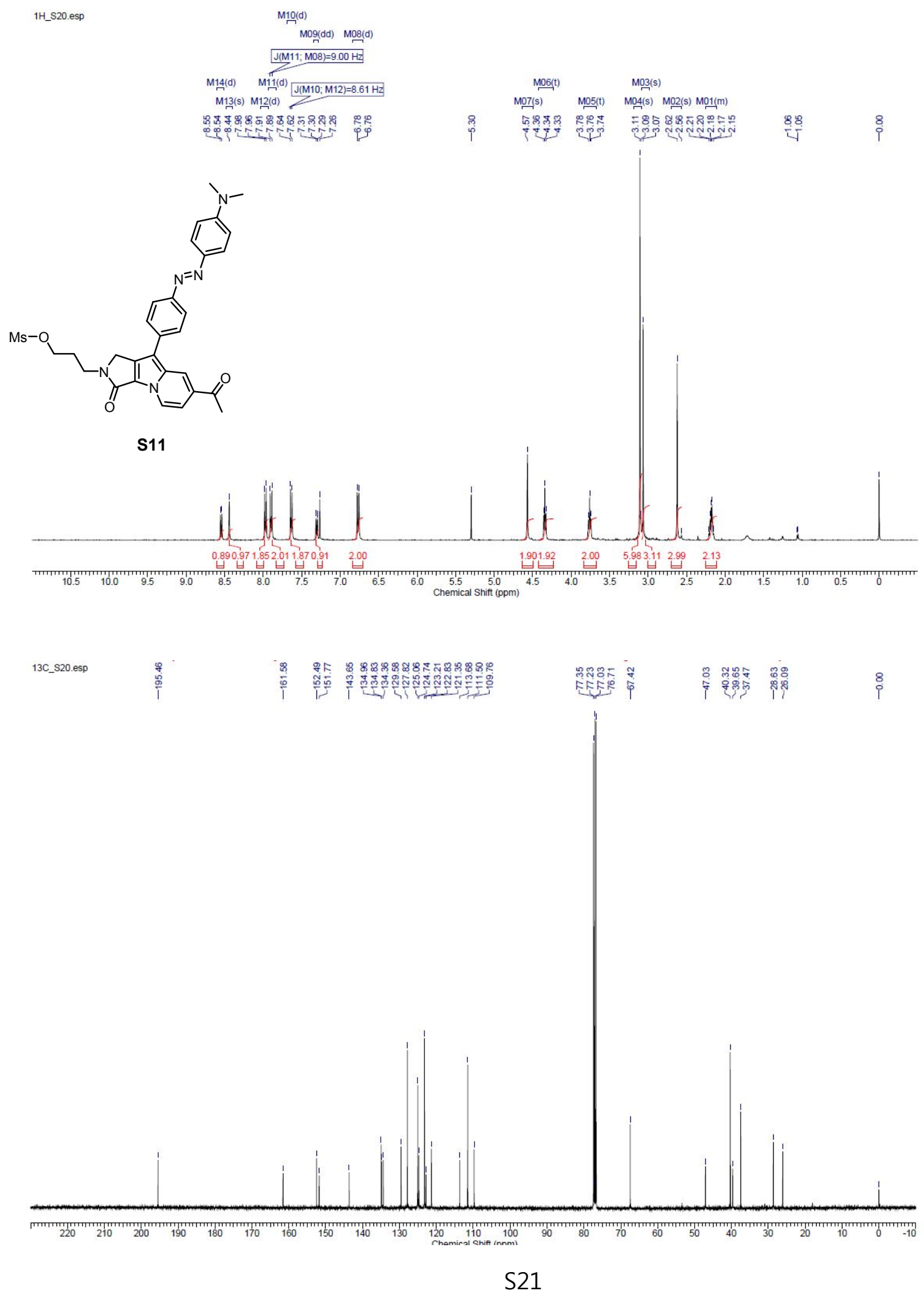


Figure S18. ${ }^{1} \mathrm{H}$ and ${ }^{13} \mathrm{C}$ NMR spectra for compound $\mathrm{S} 8$ '

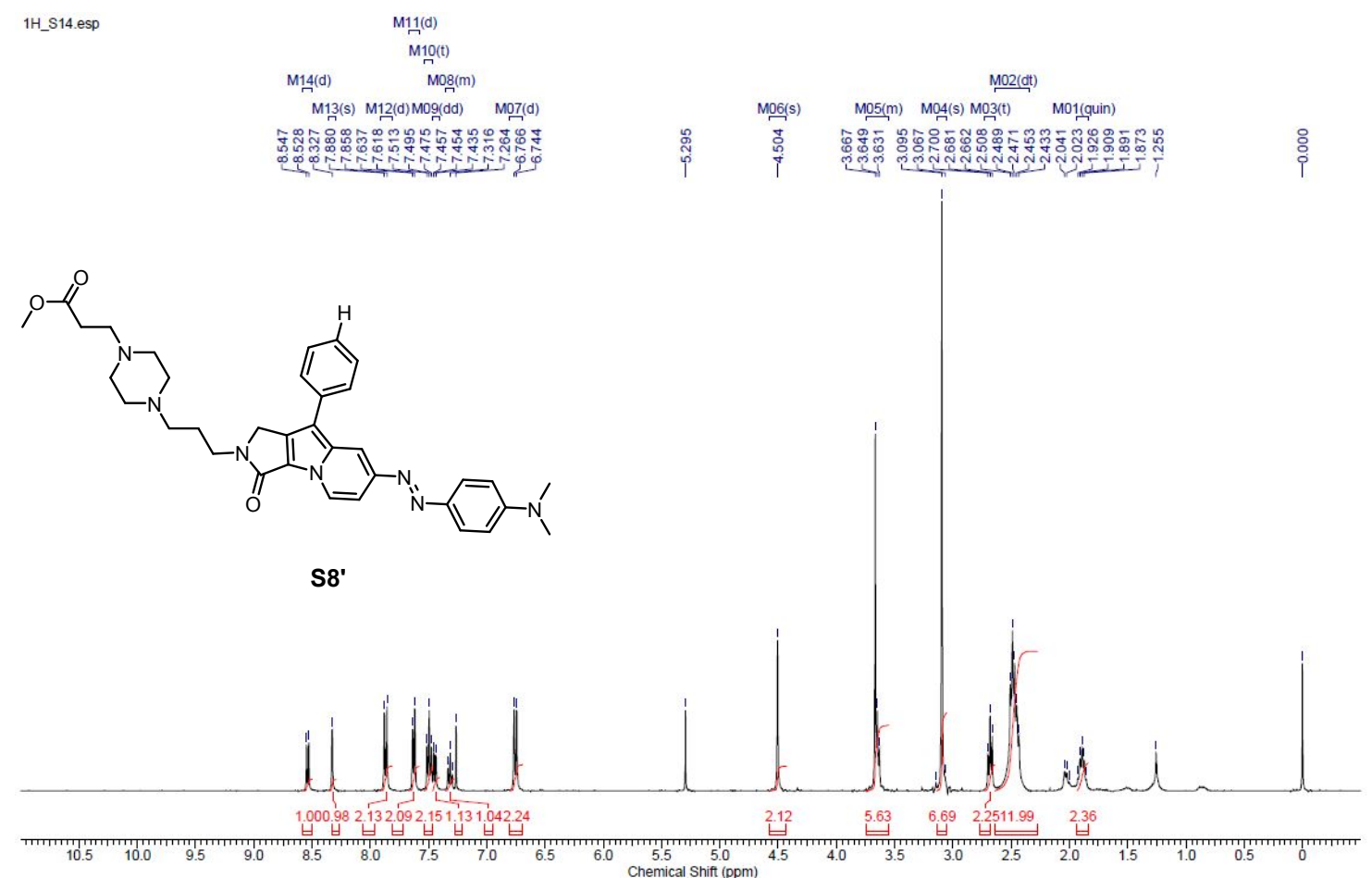

13C_S14.ESP

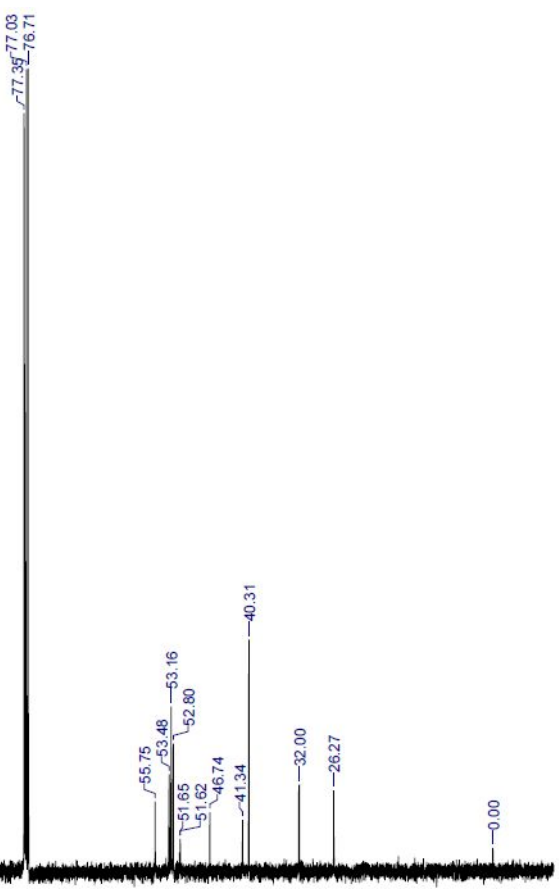

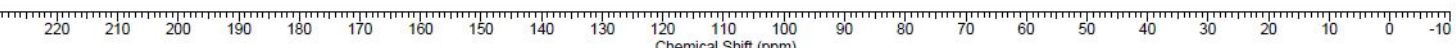


Figure S19. ${ }^{1} \mathrm{H}$ and ${ }^{13} \mathrm{C}$ NMR spectra for compound $\mathrm{S} 9 '$
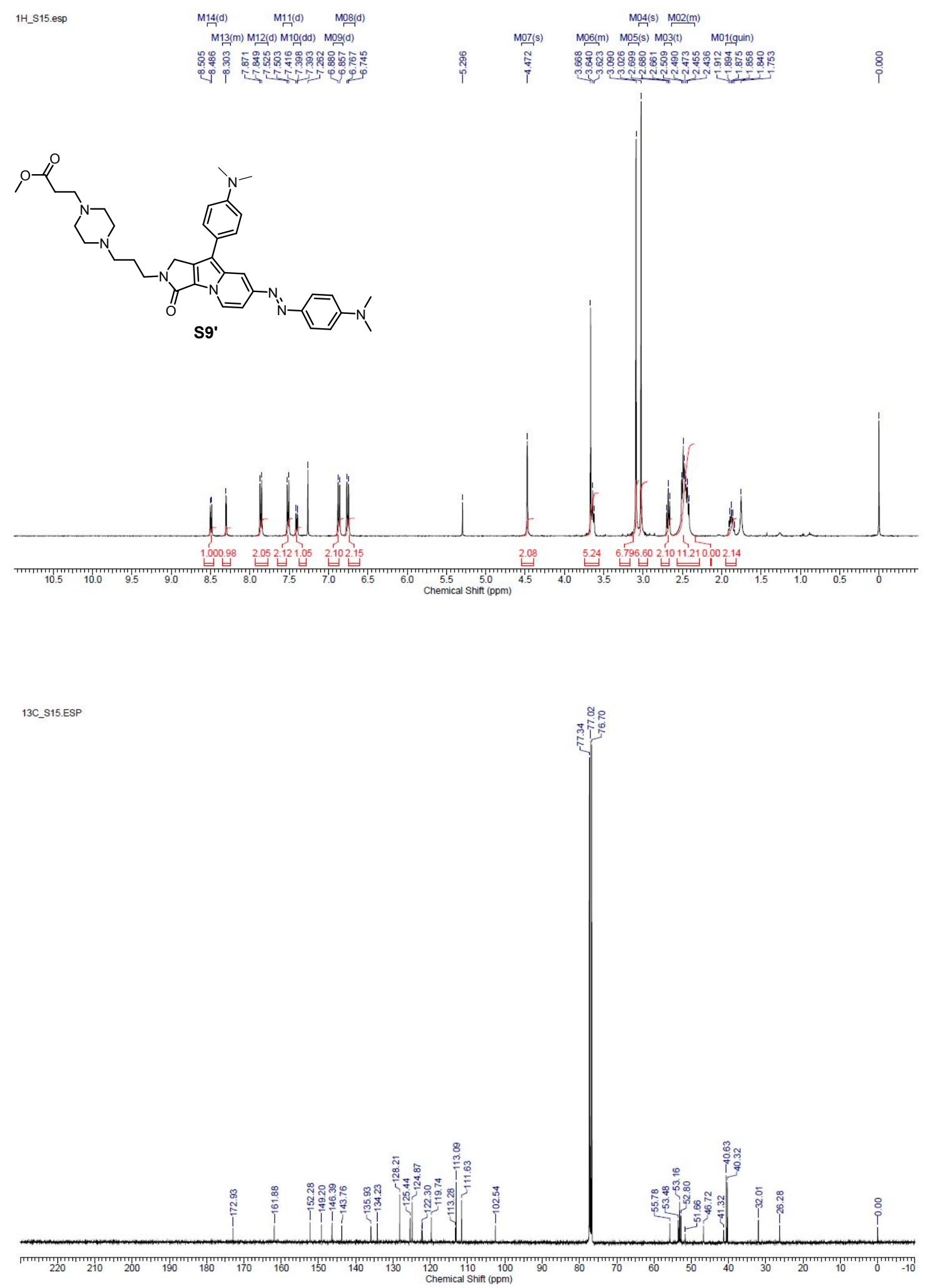
Figure S20. ${ }^{1} \mathrm{H}$ and ${ }^{13} \mathrm{C}$ NMR spectra for compound $\mathrm{S} 10^{\prime}$

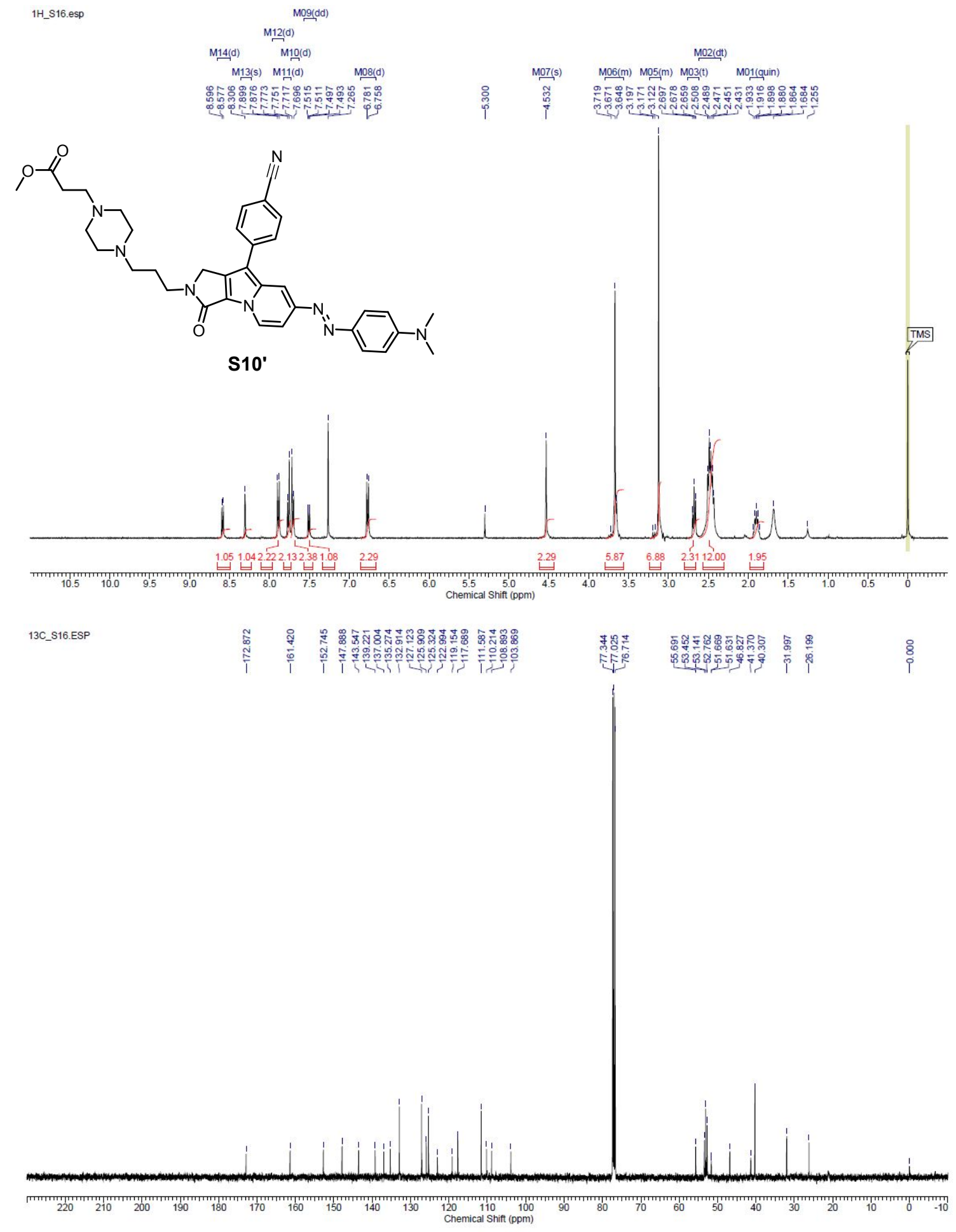


Figure S21. ' H NMR spectrum for compound S11'

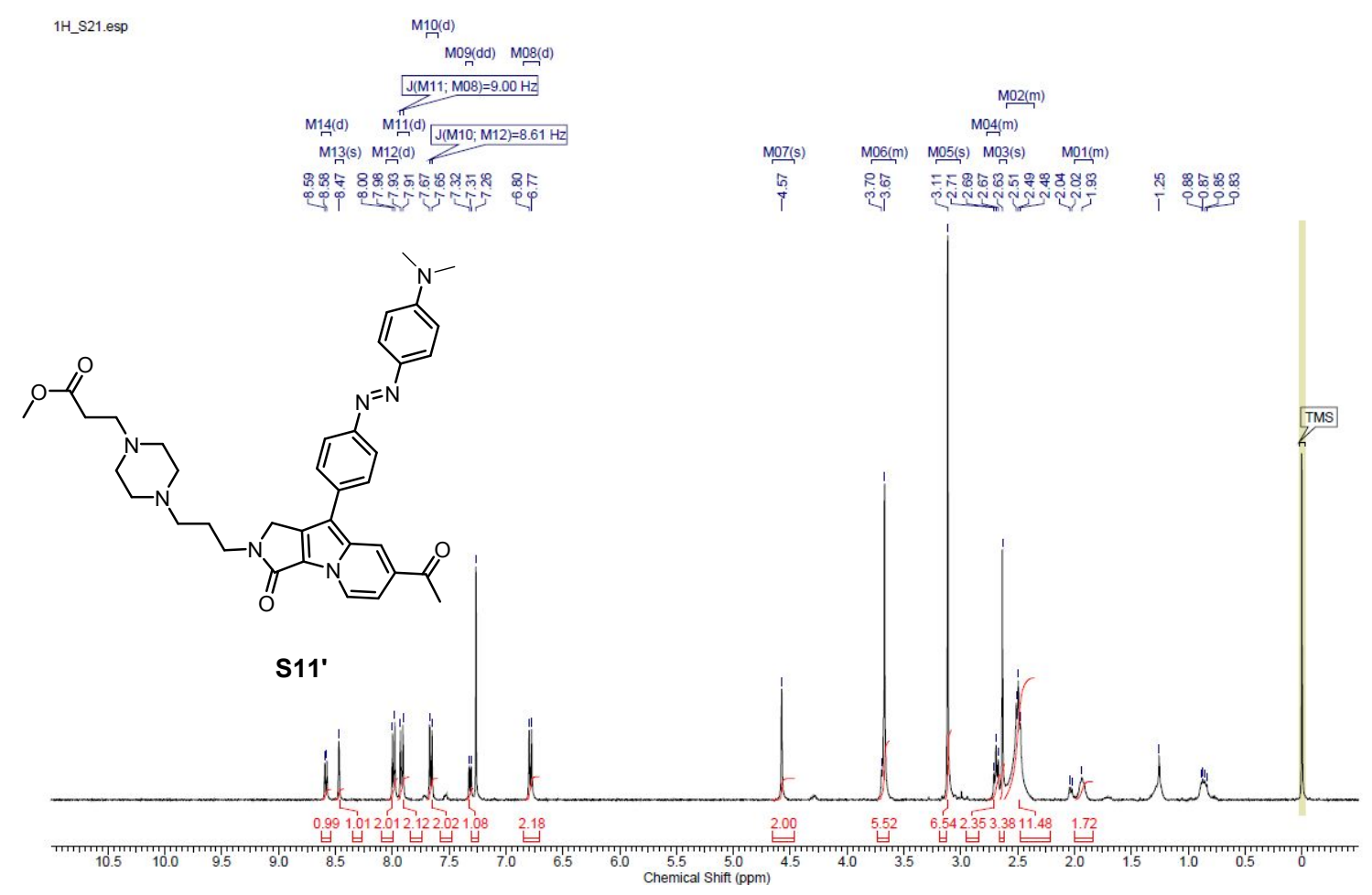


Figure S22. HRMS spectra for compound S1

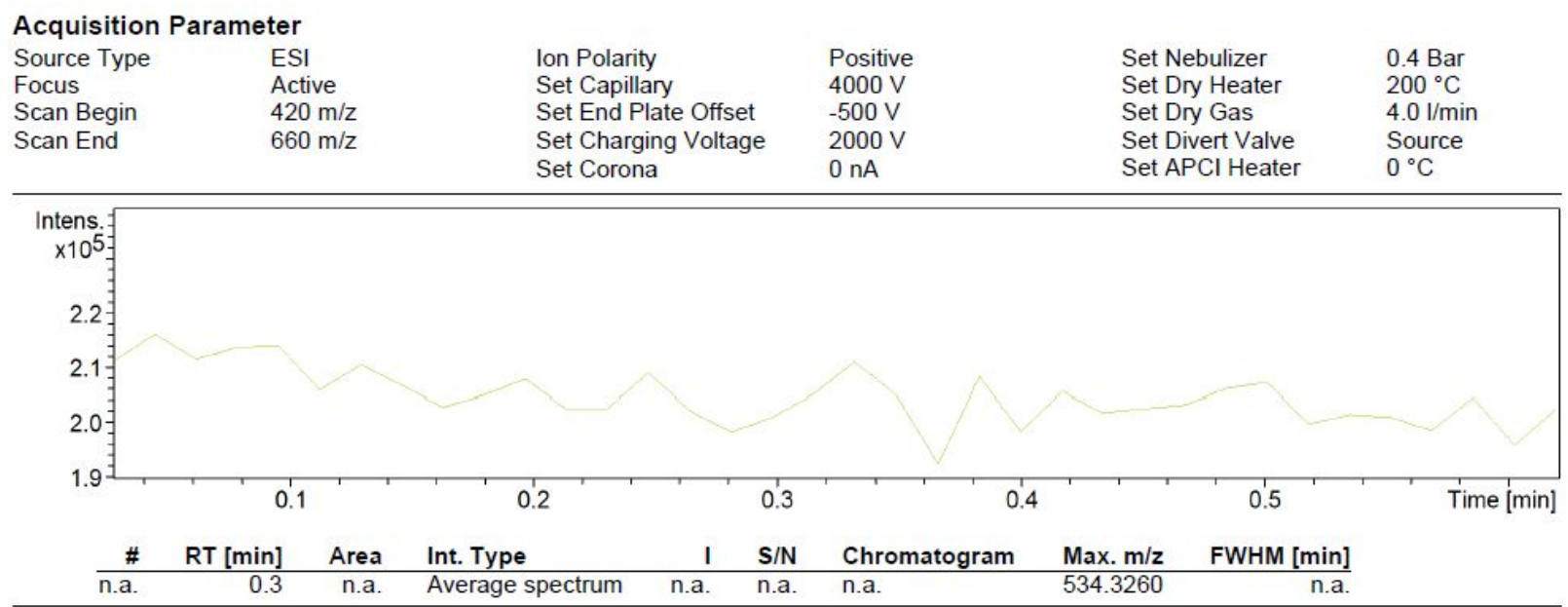

+MS, $0.2-0.5 \mathrm{~min} \# 10-29$

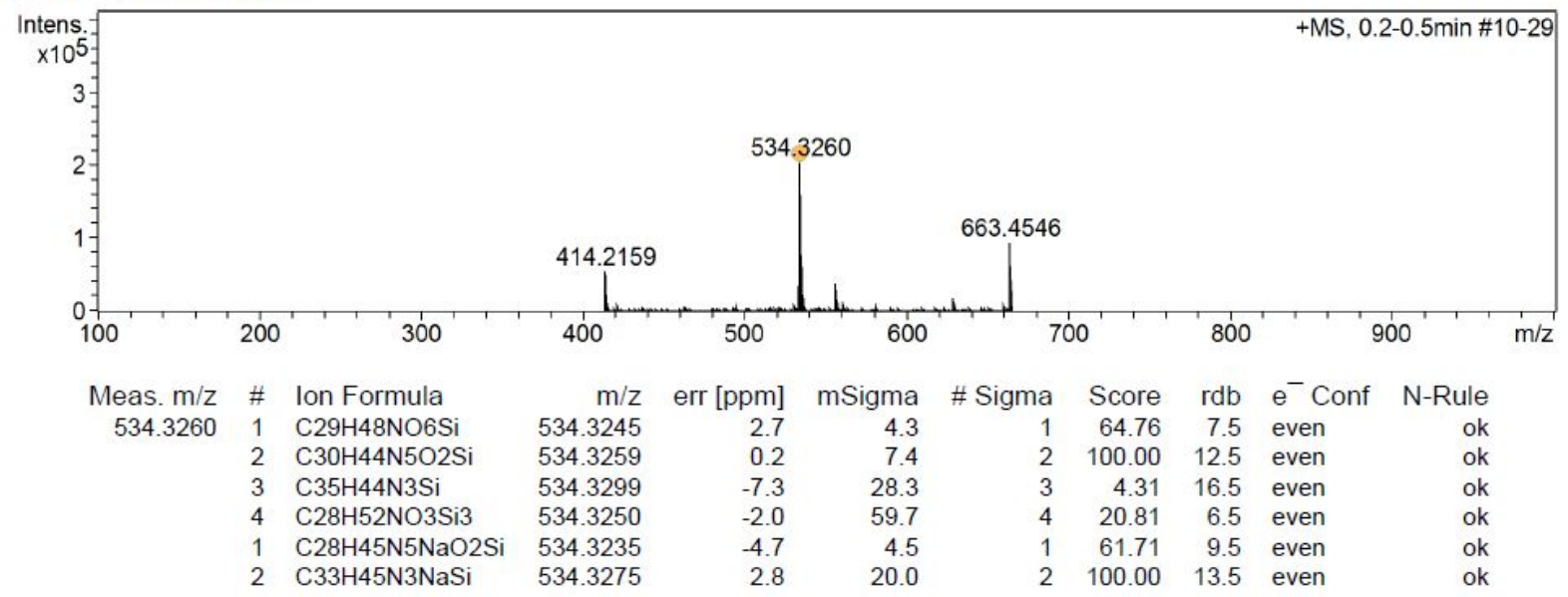


Figure S23. HRMS spectra for compound S2

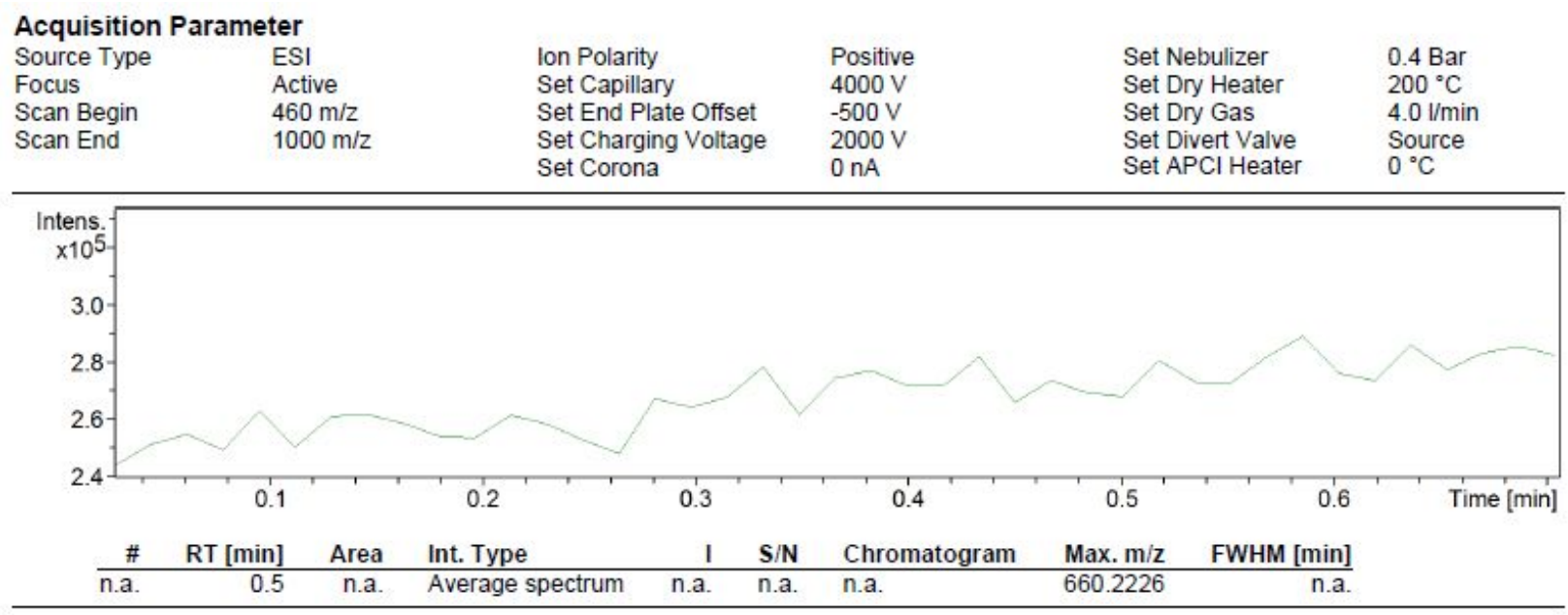

+MS, 0.3-0.7min \#19-39

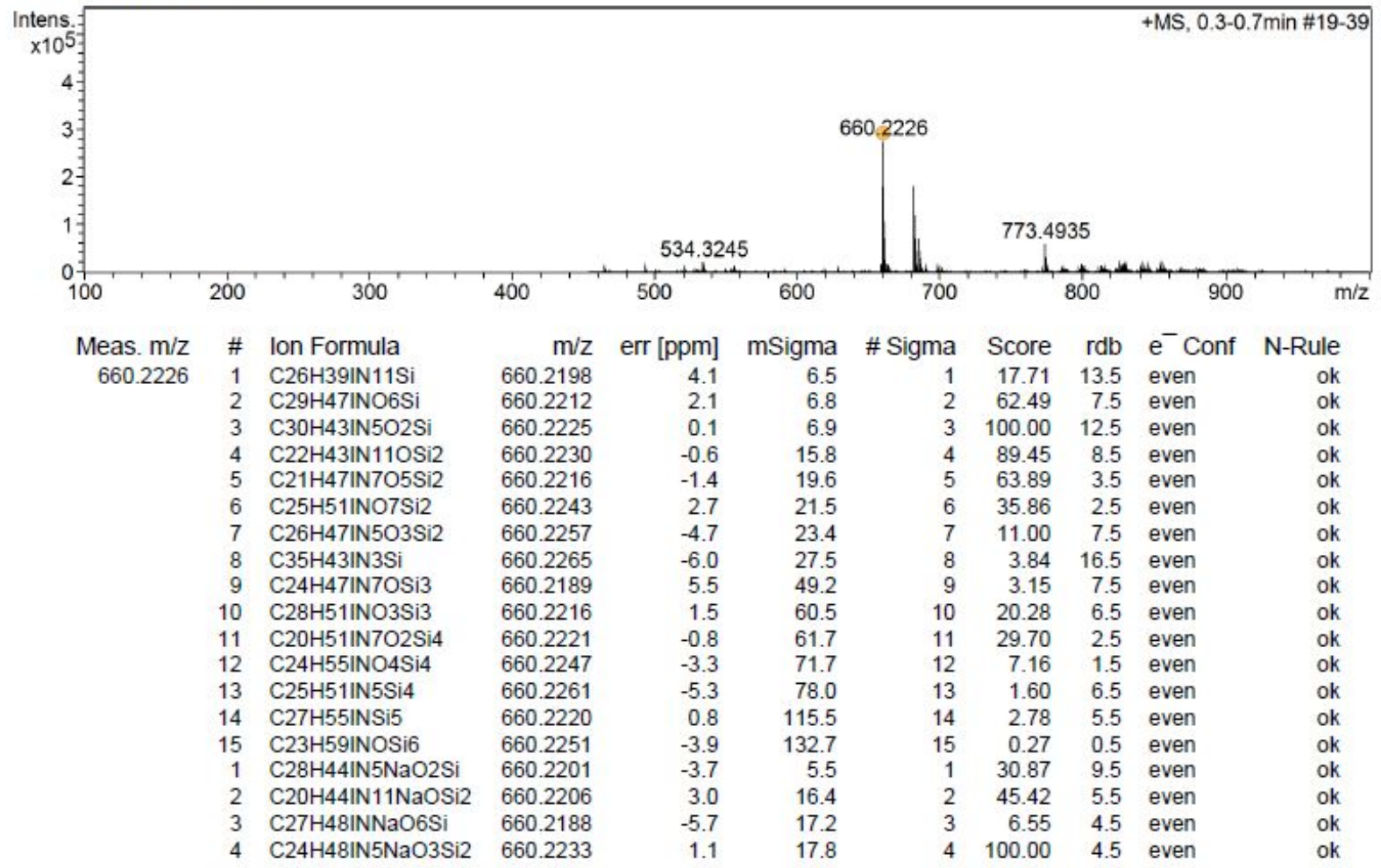


Figure S24. HRMS spectra for compound S3

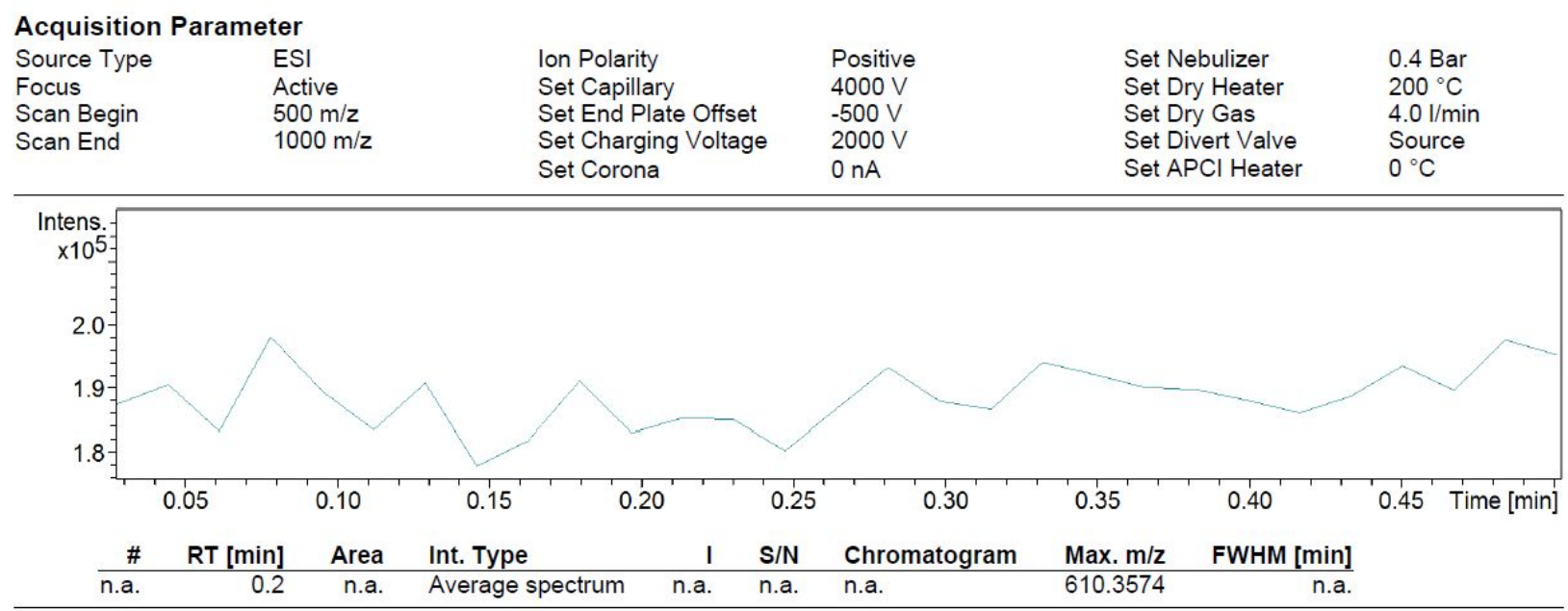

+MS, 0.1-0.3min \#4-20

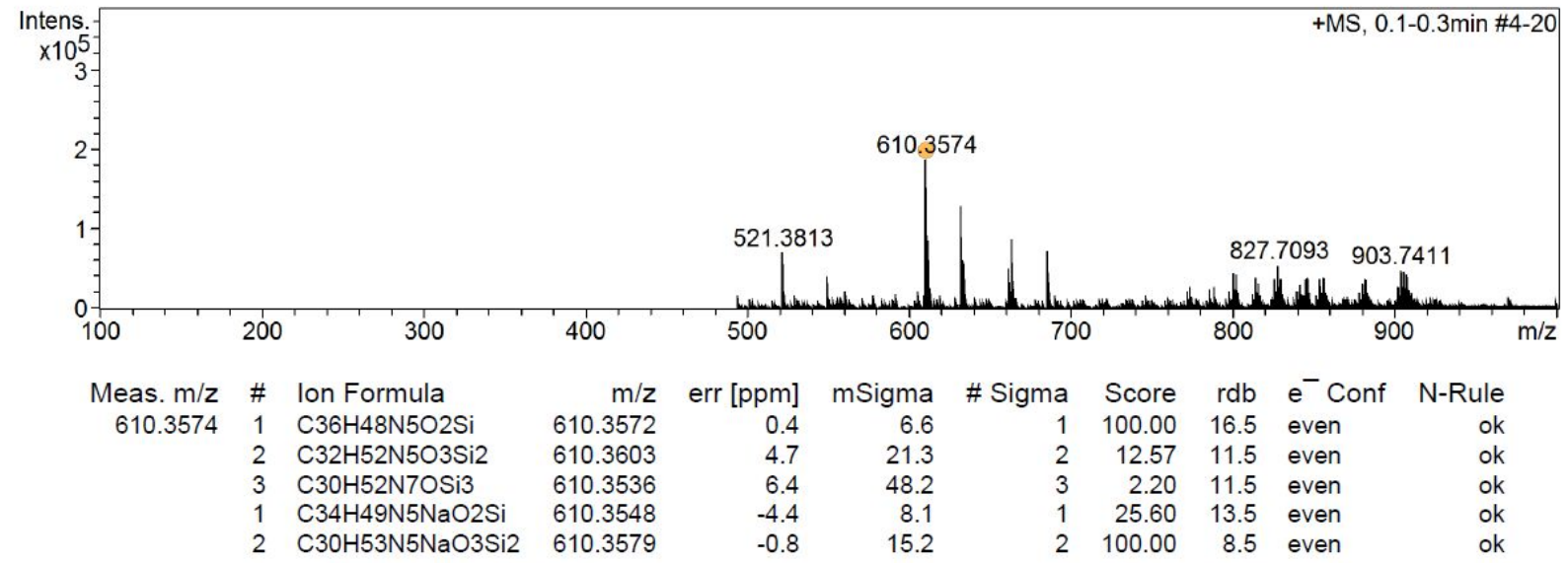


Figure S25. HRMS spectra for compound S4

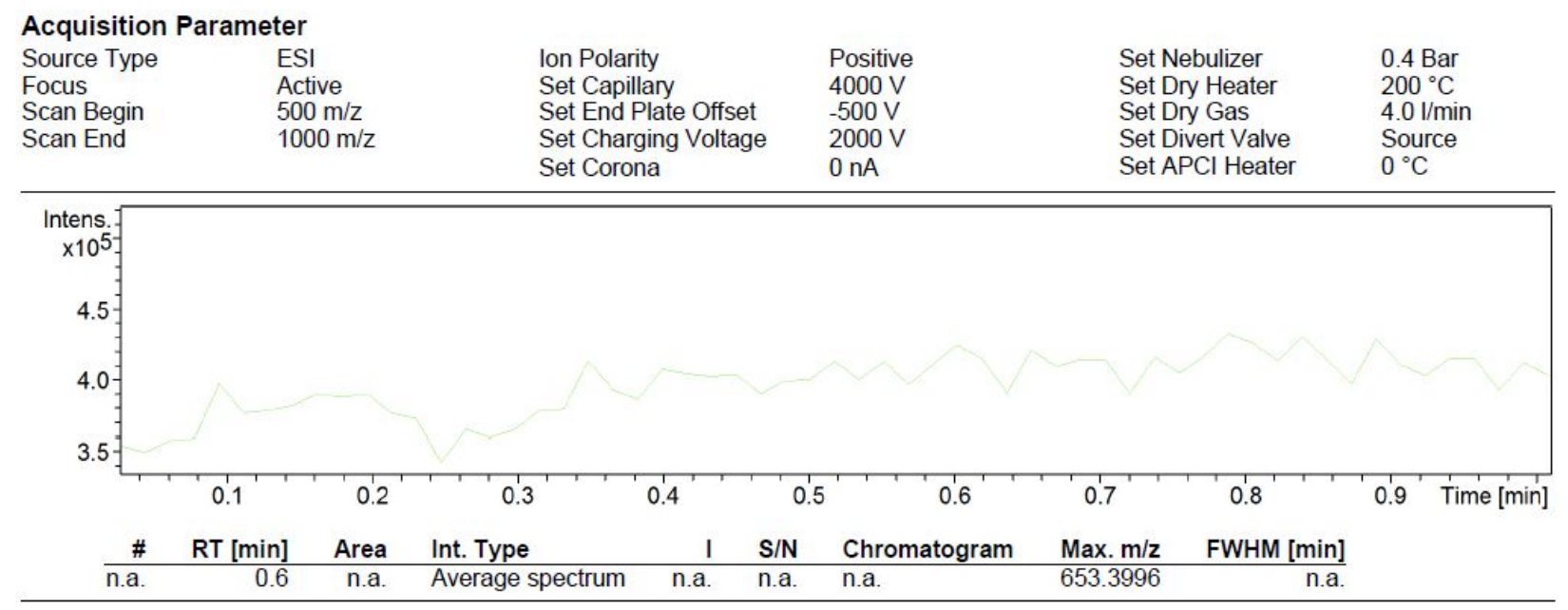

+MS, 0.3-0.9min \#16-50

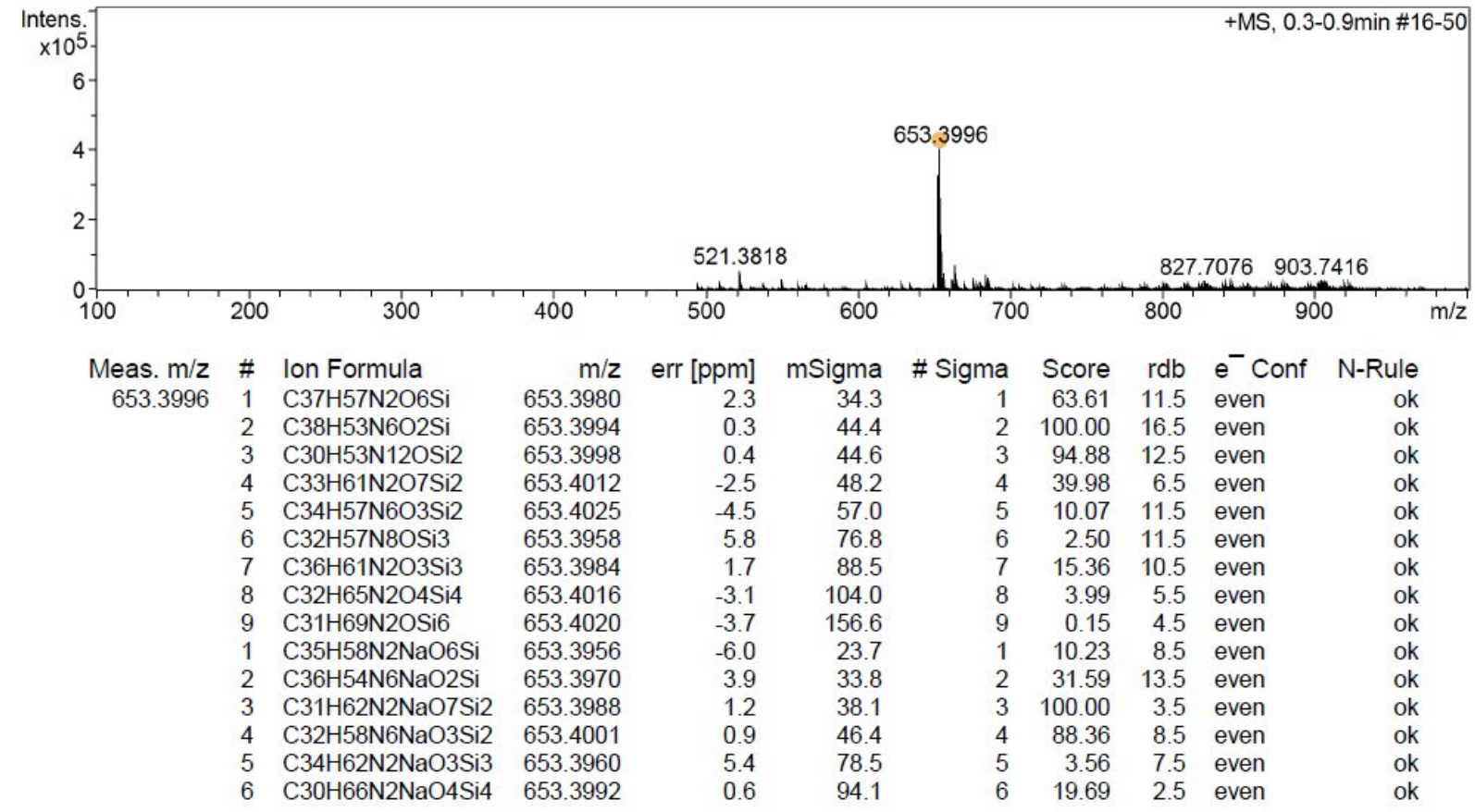


Figure S26. HRMS spectra for compound S5

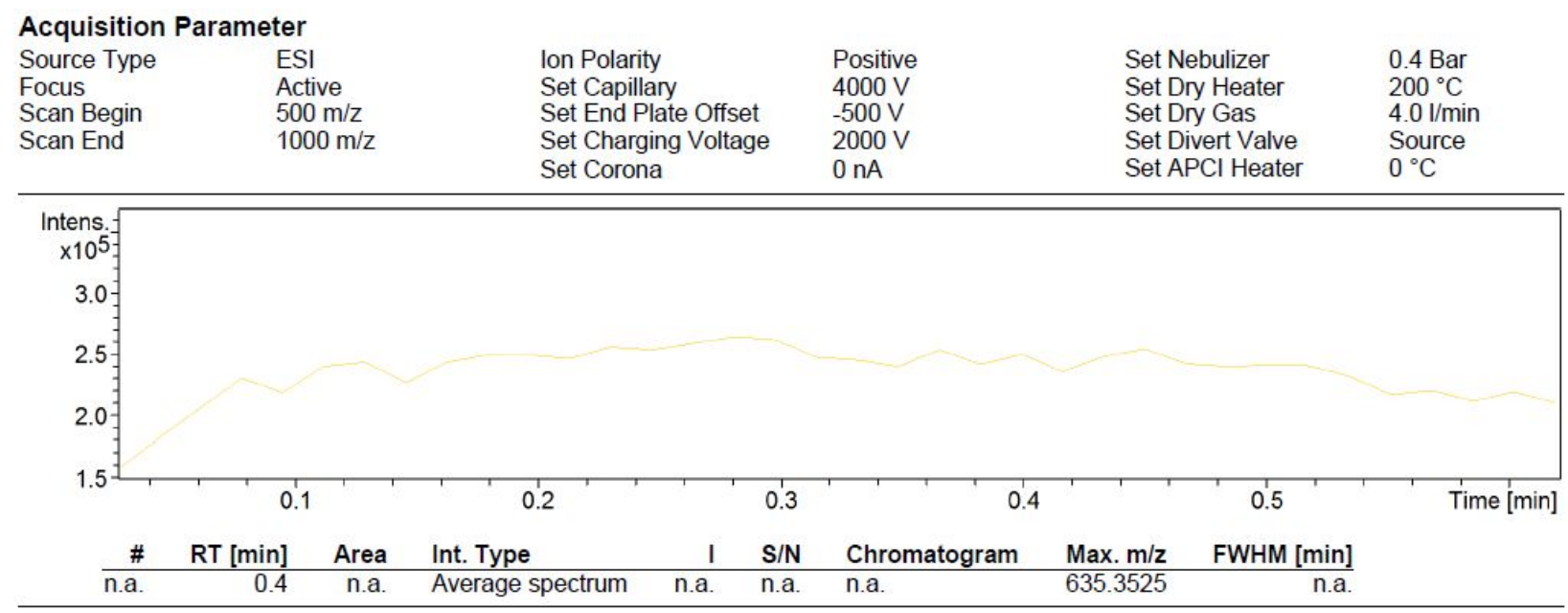

+MS, 0.3-0.6min \#15-35

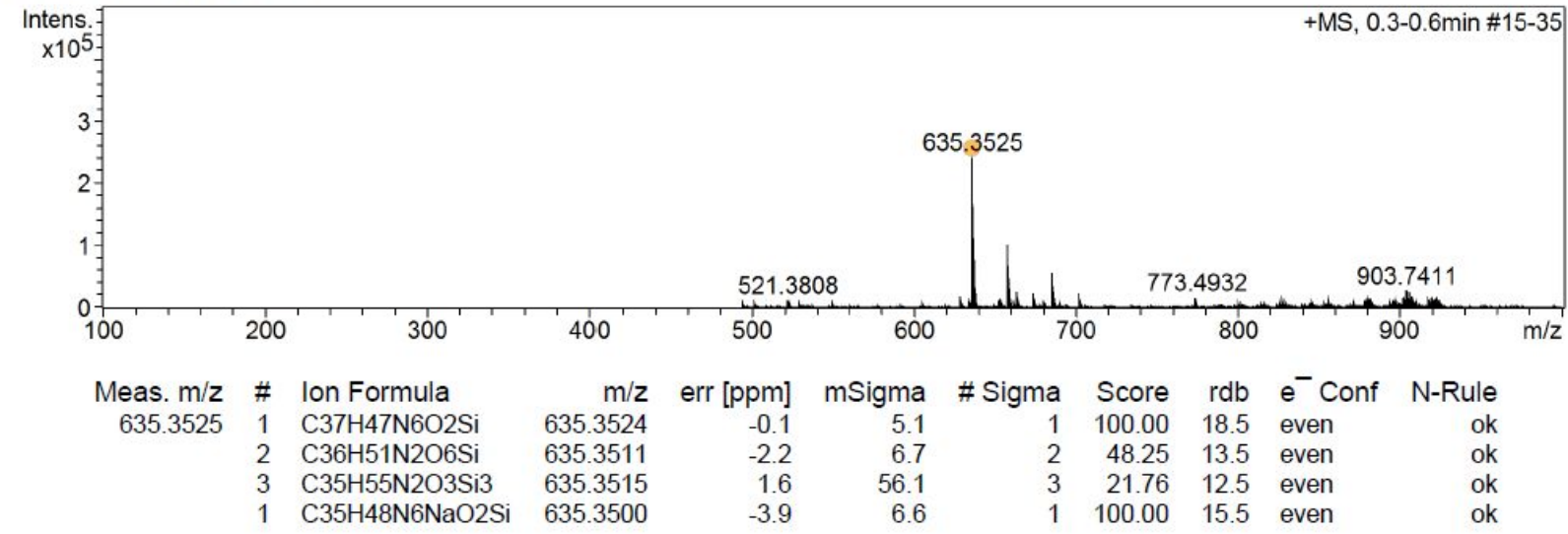


Figure S27. HRMS spectra for compound S6

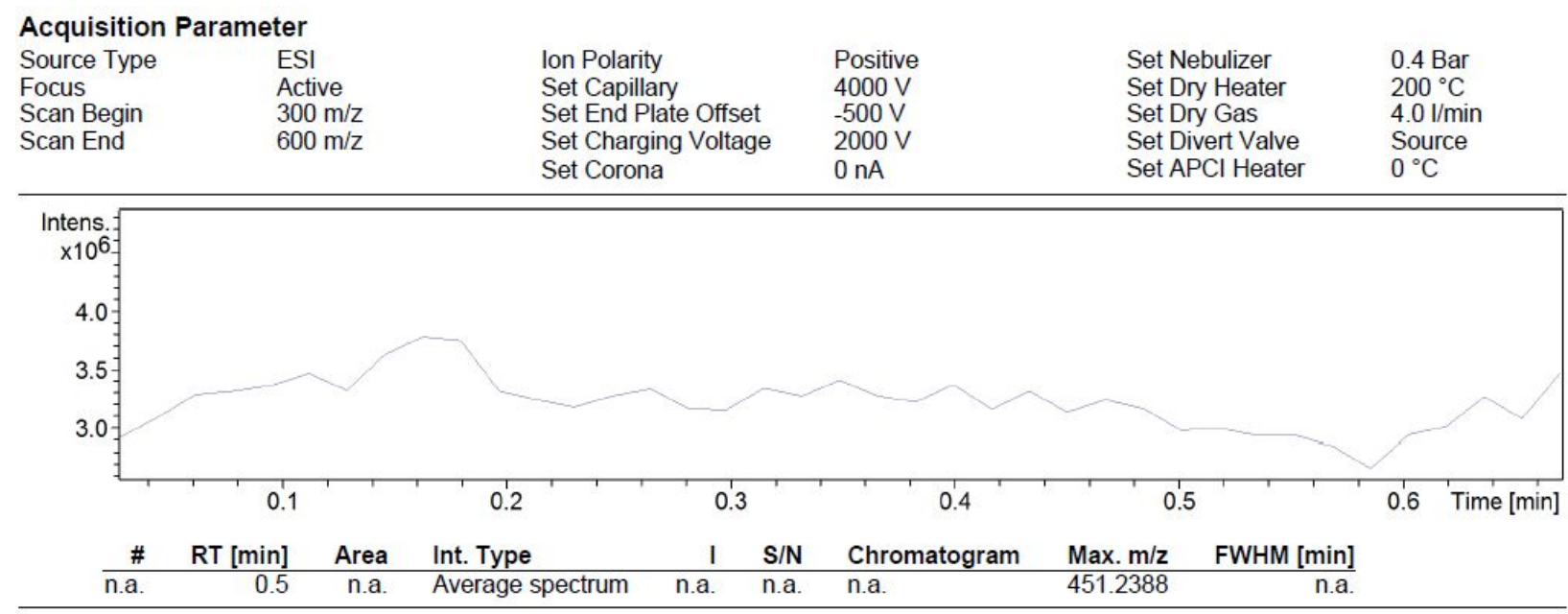

+MS, 0.4-0.7min \#24-38

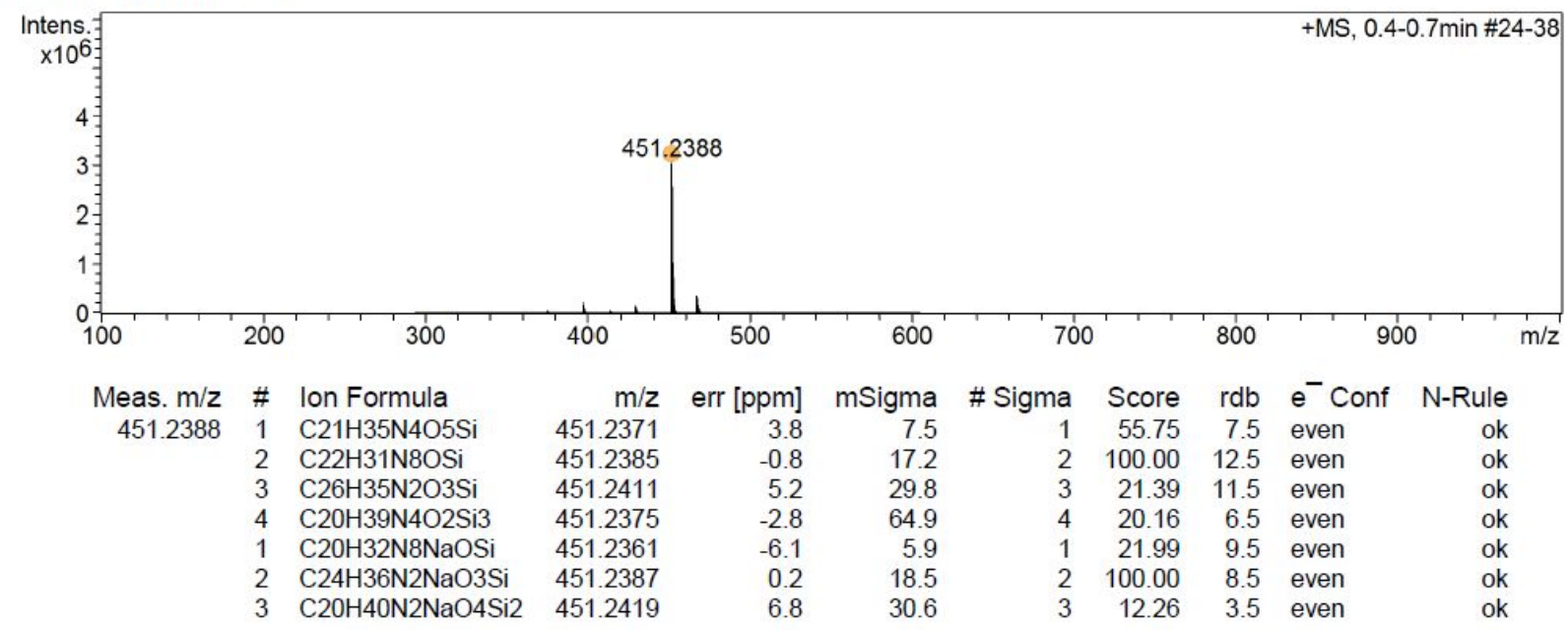


Figure S28. HRMS spectra for compound S7

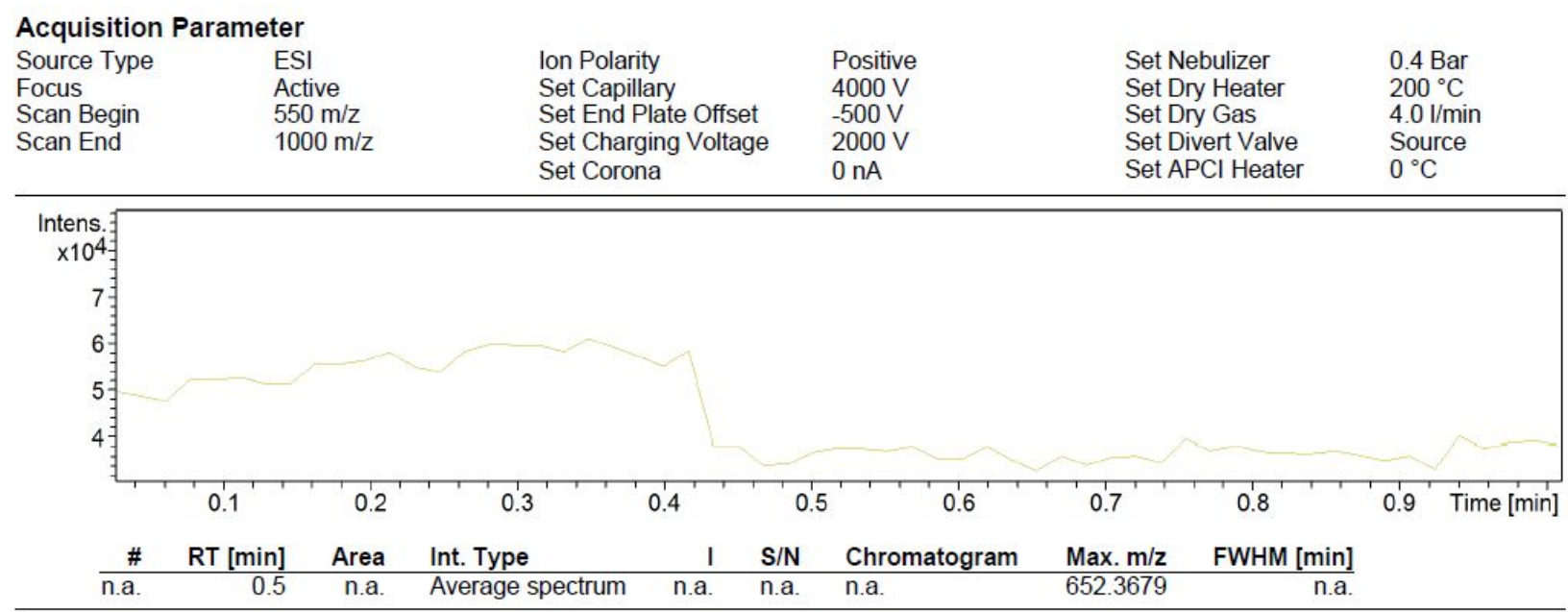

+MS, 0.2-0.8min \#9-48

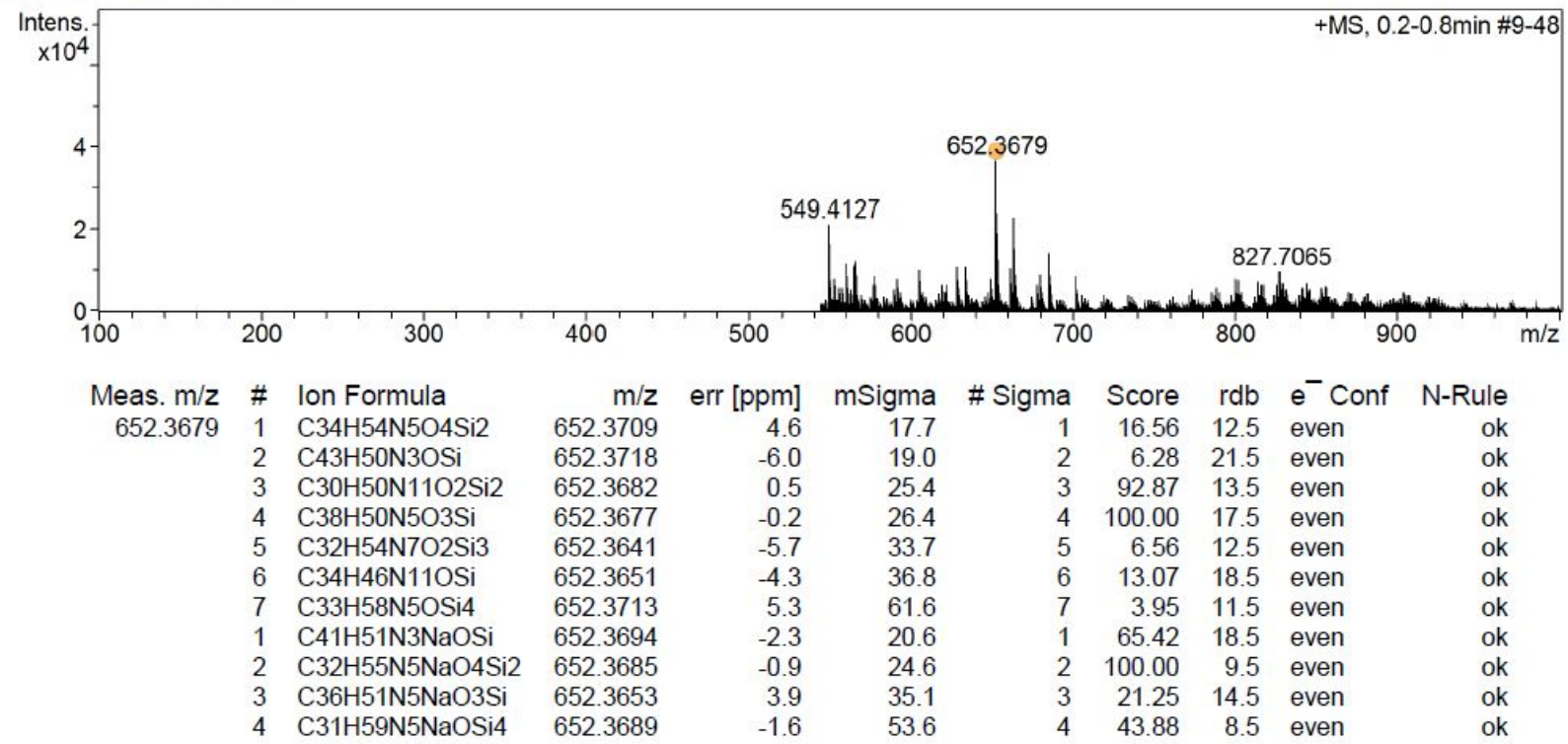


Figure S29. HRMS spectra for SF-Azo 01

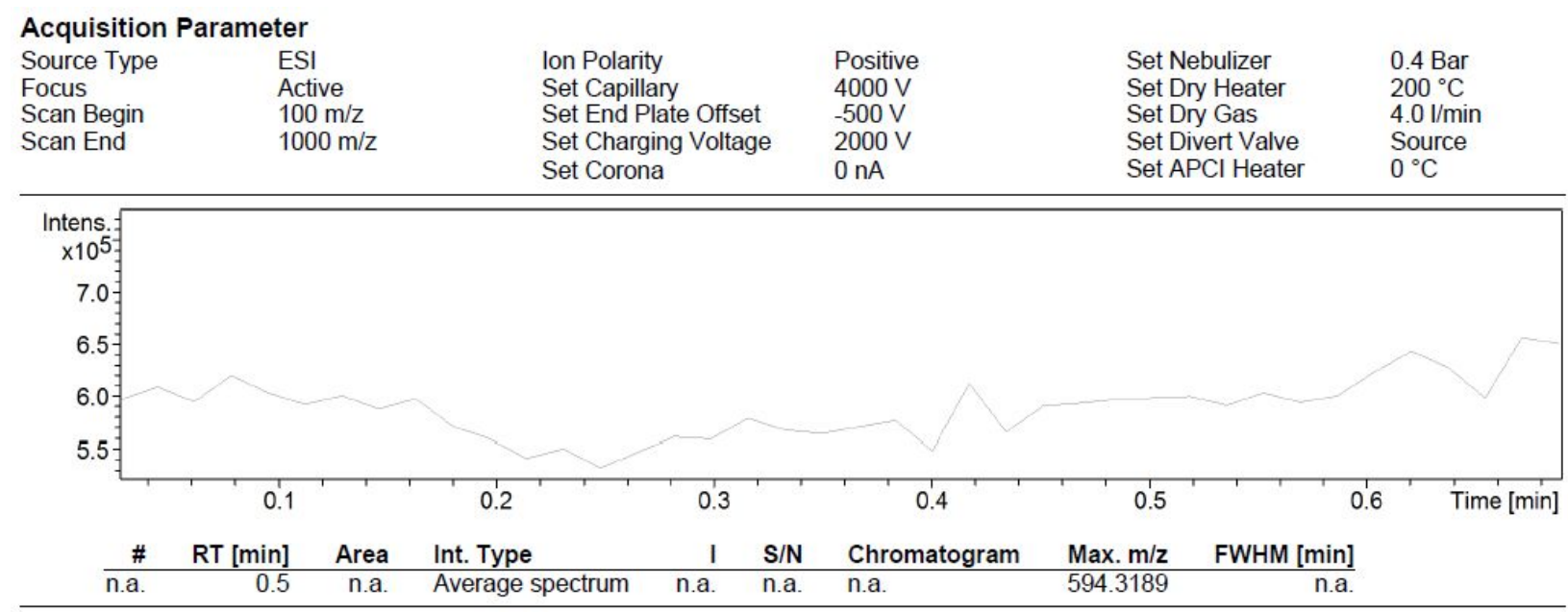

+MS, 0.4-0.7min \#22-39

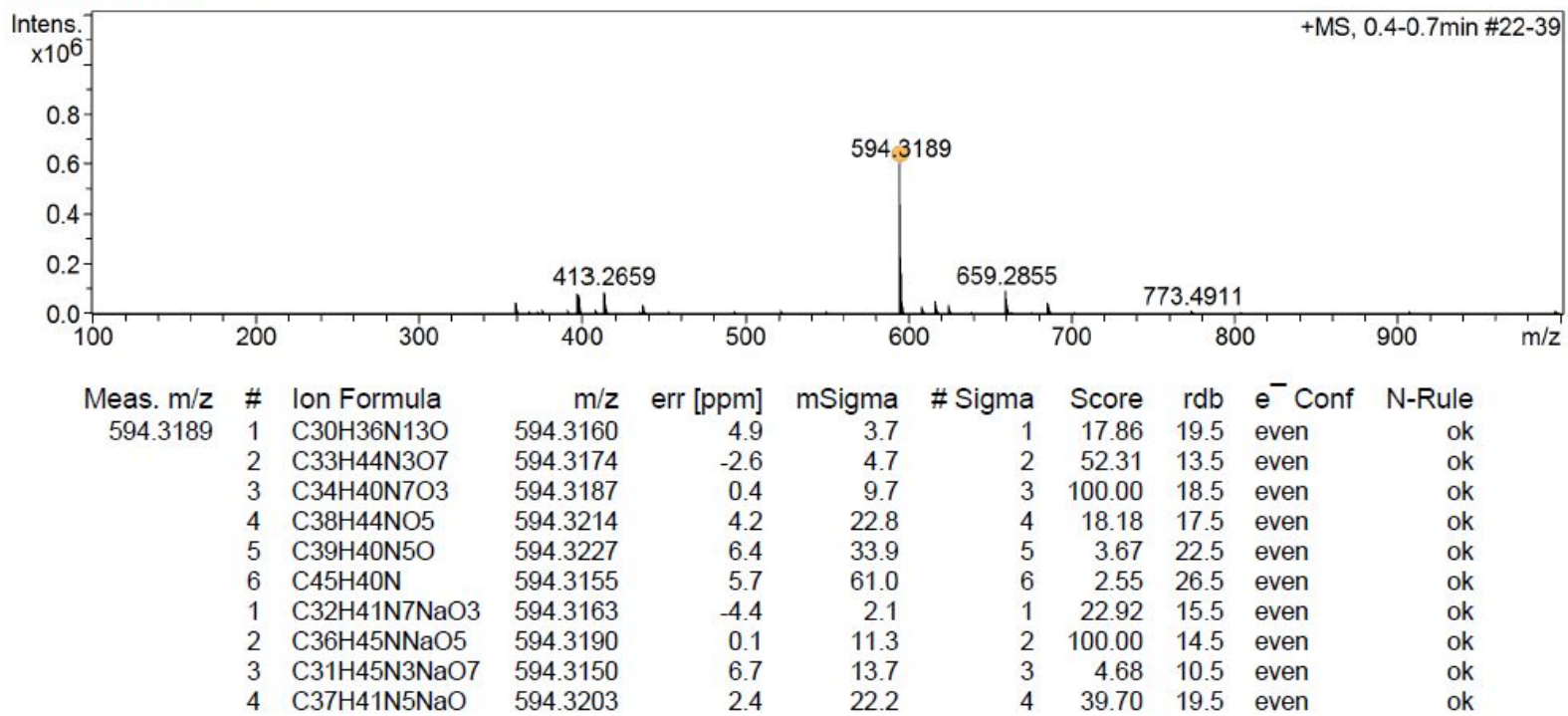


Figure S30. HRMS spectra for SF-Azo 02

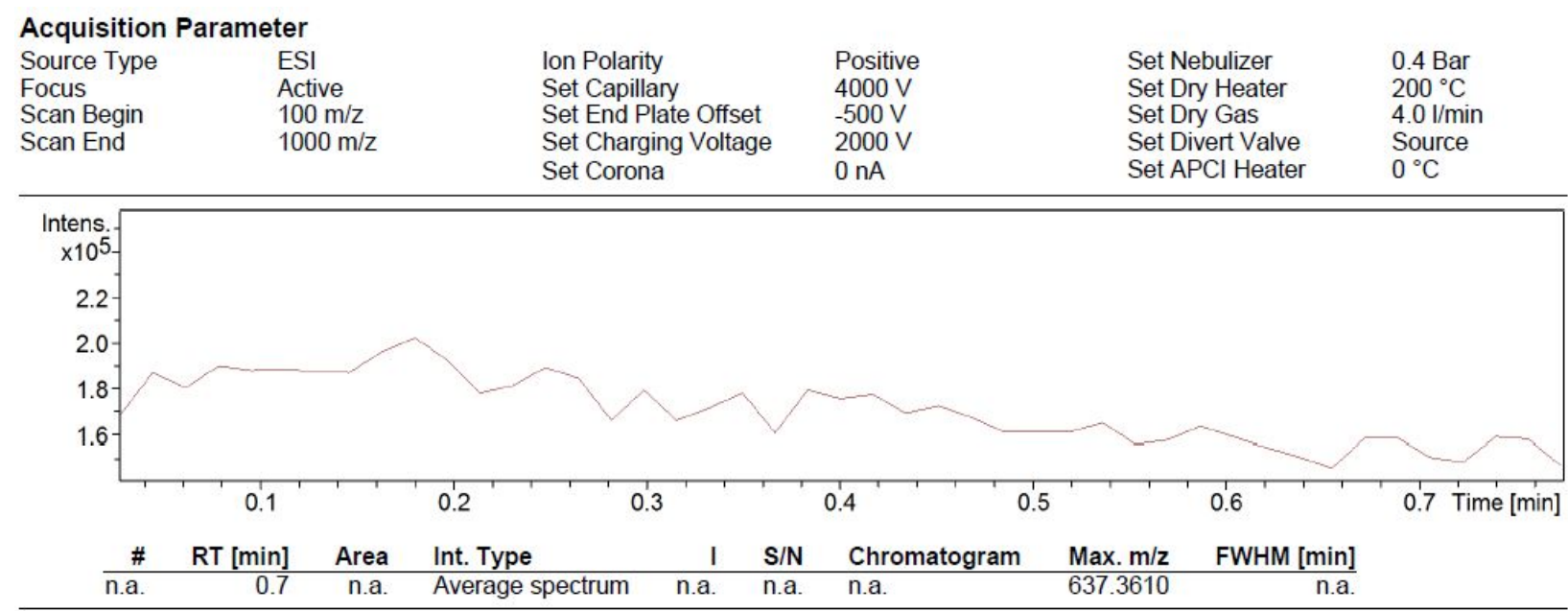

+MS, 0.6-0.8min \#33-44

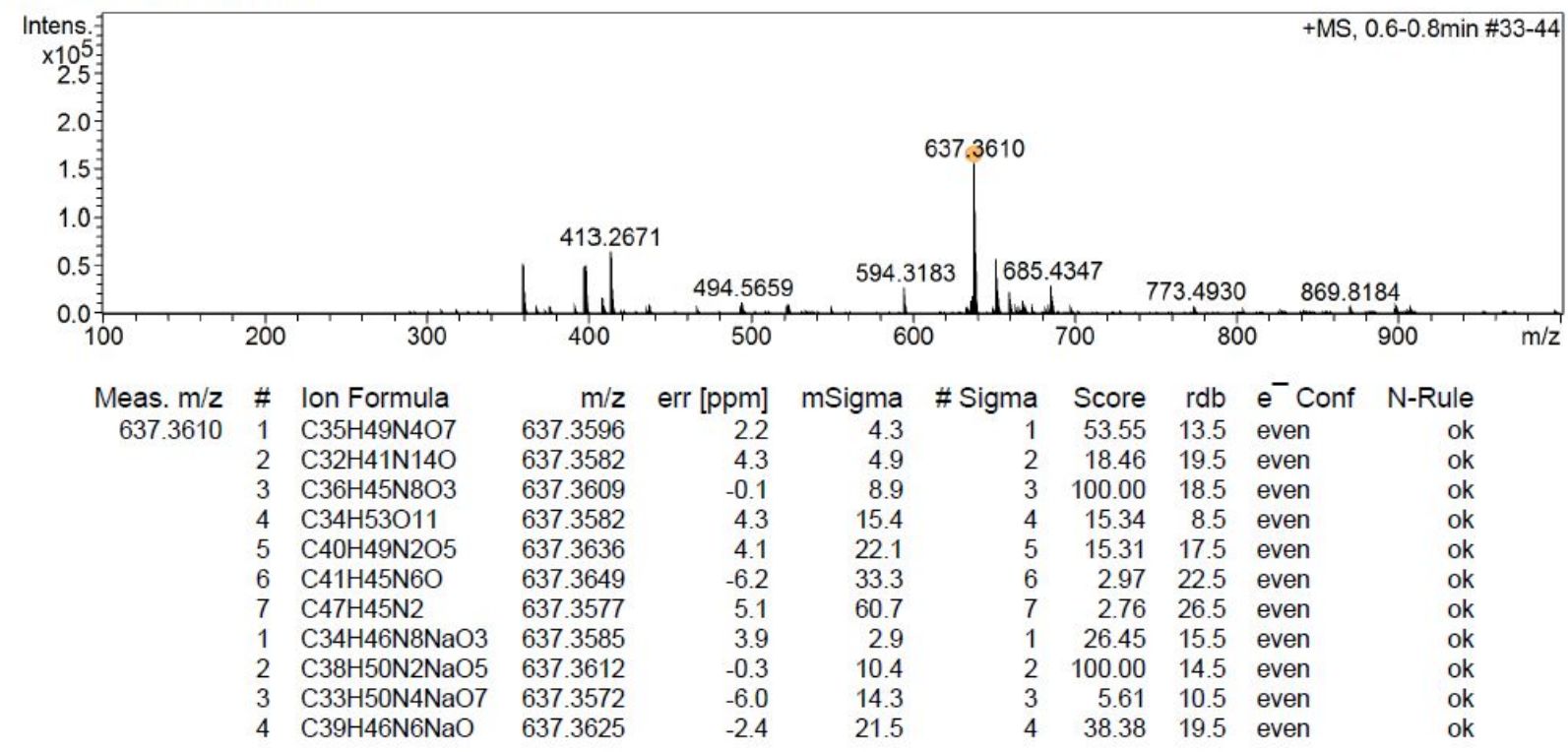


Figure S31. HRMS spectra for SF-Azo 03

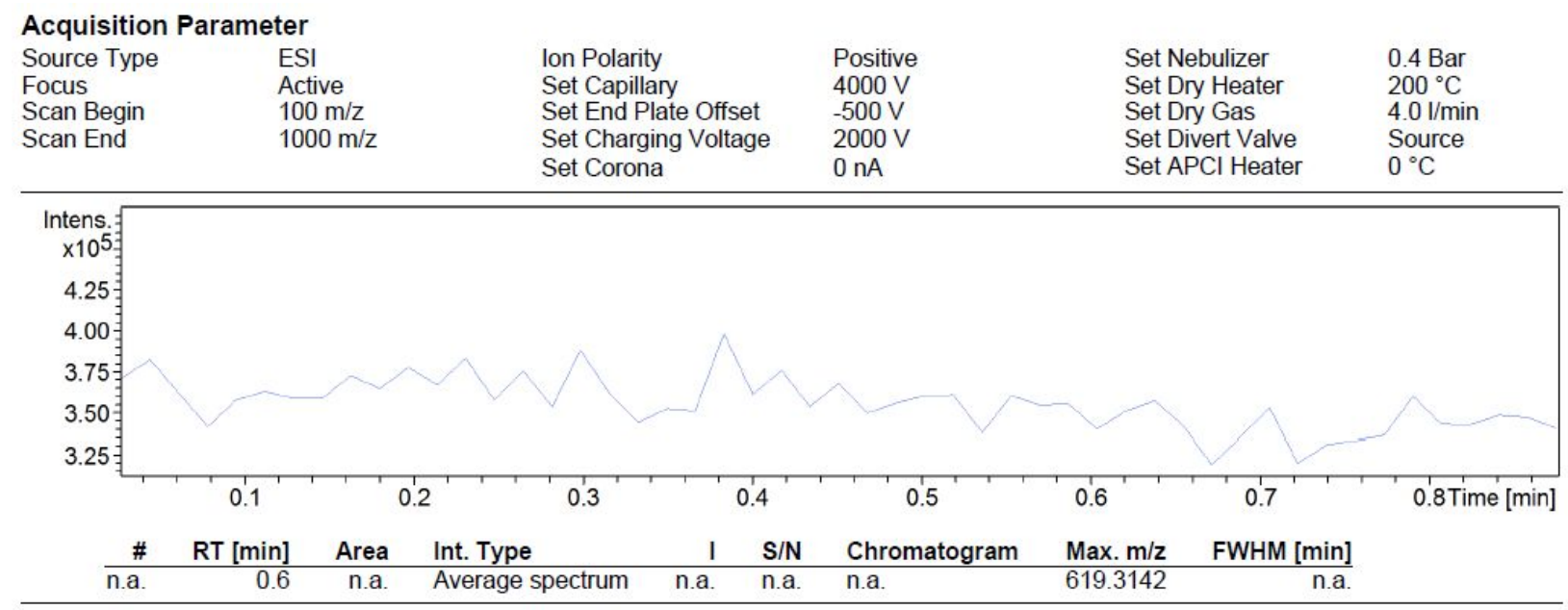

+MS, 0.4-0.8min \#25-49

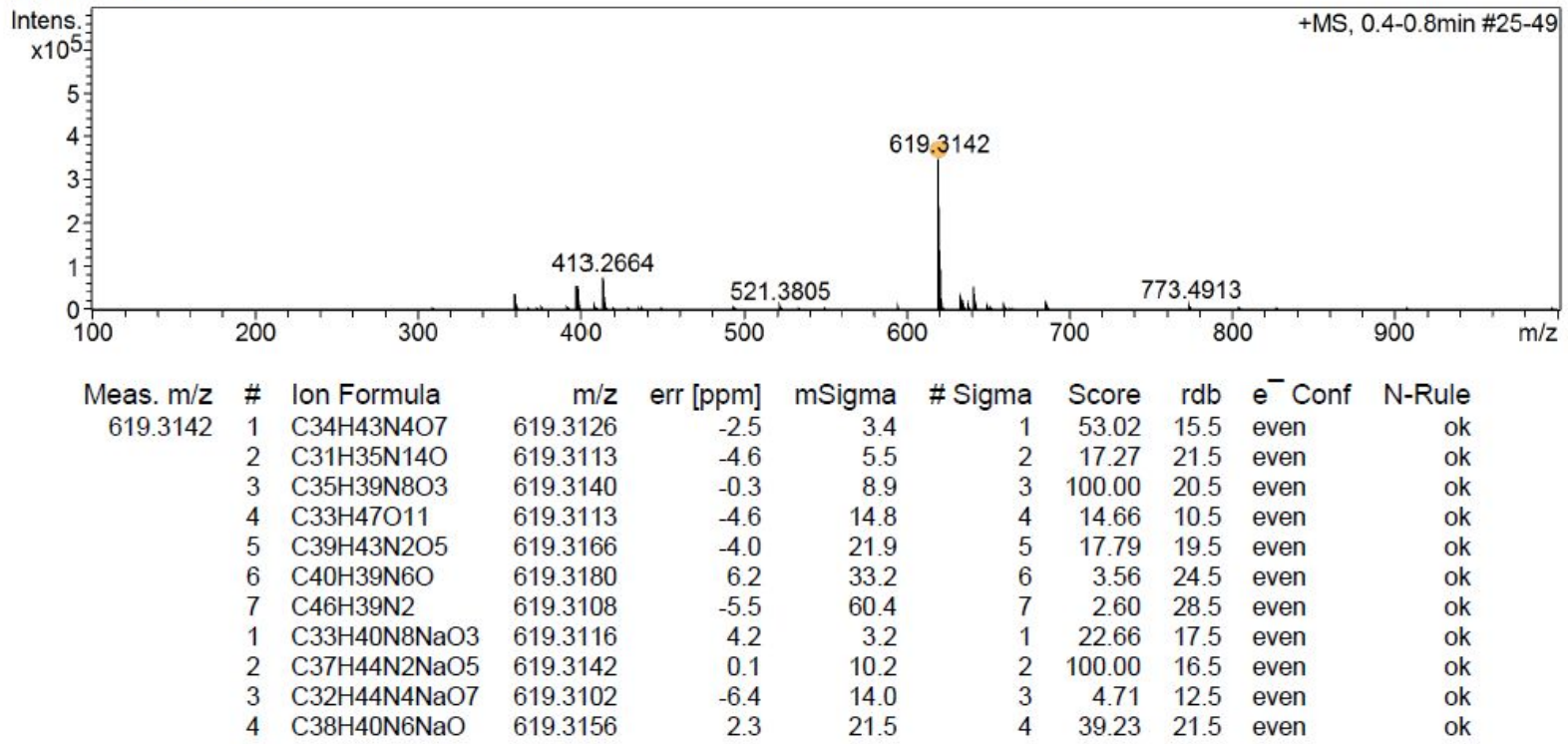


Figure S32. HRMS spectra for SF-Azo 04

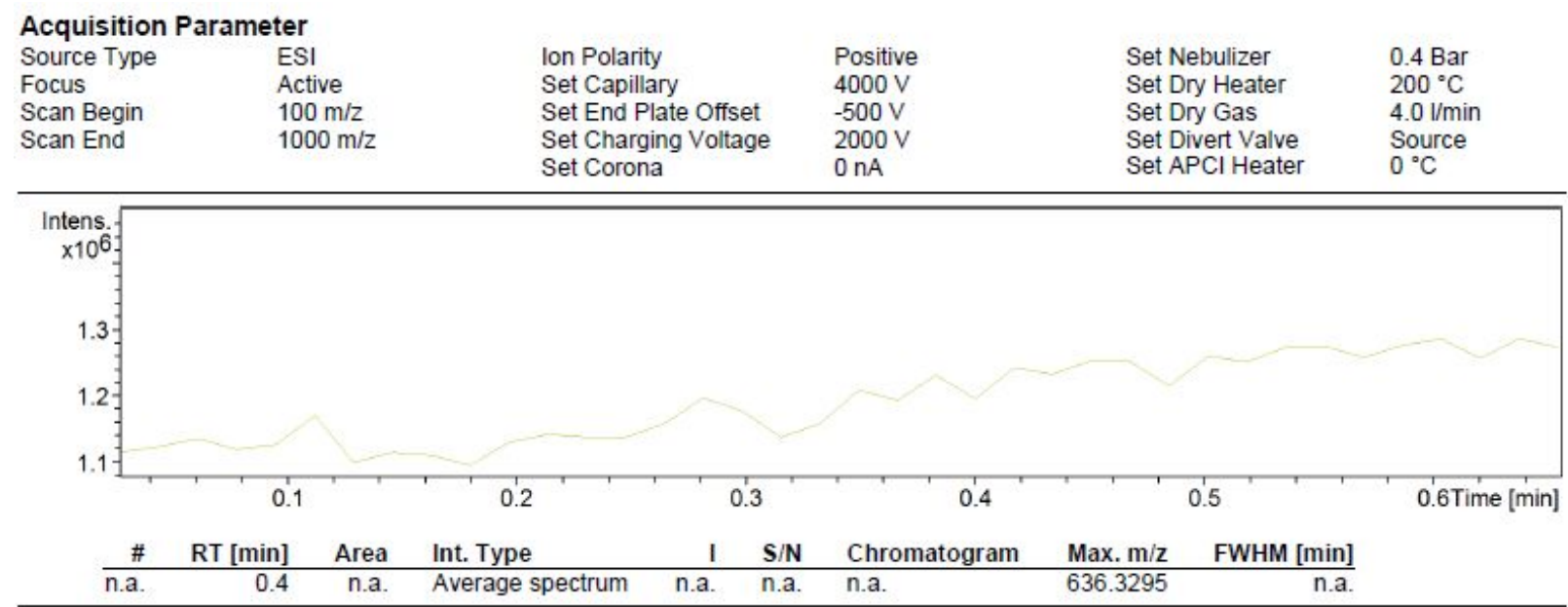

+MS, 0.2-0.6min \#13-35

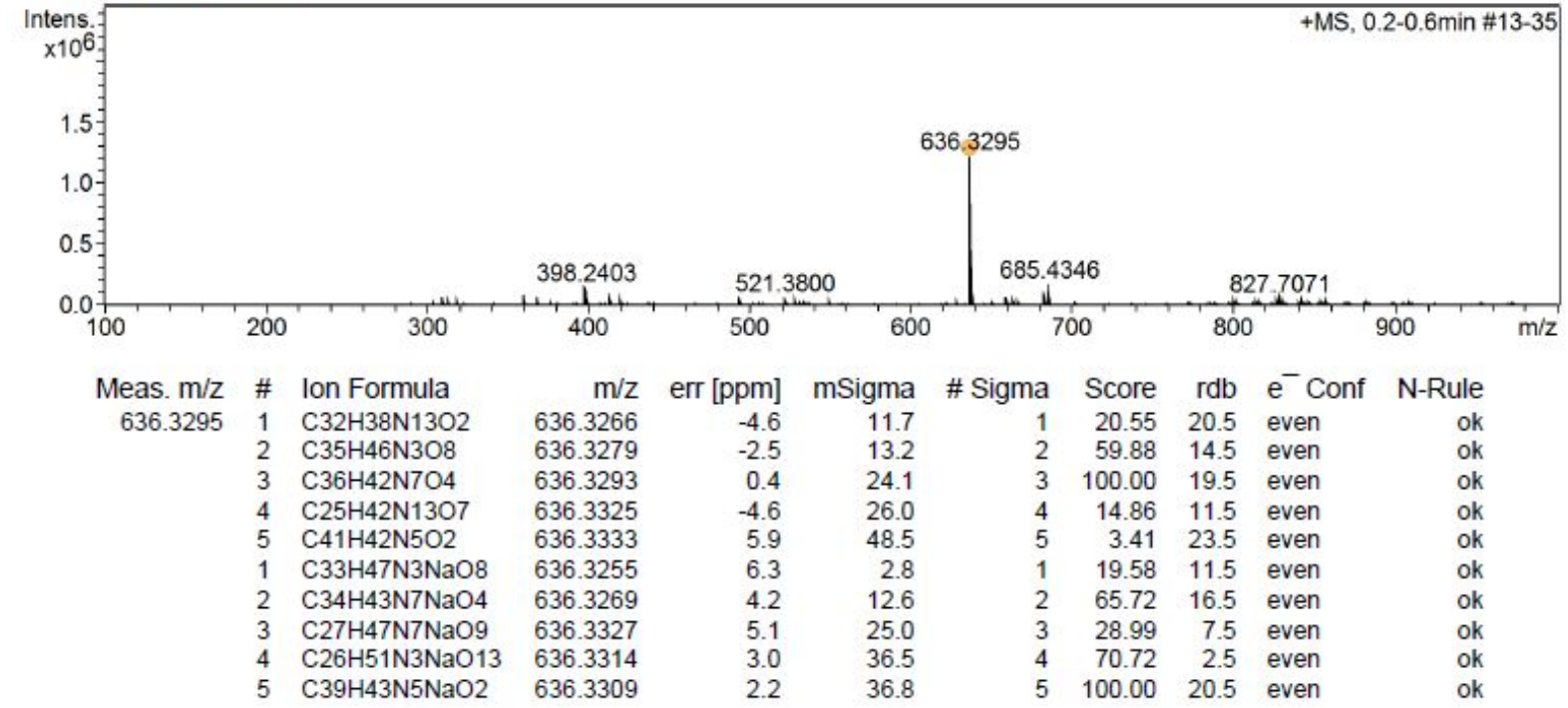

